\title{
Strukturalne, litologiczne oraz tektoniczne uwarunkowania rozwoju i ewolucji świętokrzyskich skałek piaskowcowych
}

\author{
Jan Urban ${ }^{1}$
}

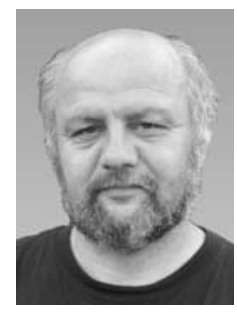

Structural, lithological and tectonic constraints on the development and evolution of sandstone tors in the Świętokrzyskie (Holy Cross) Mountains. Prz. Geol., 68: 112-126; doi: 10.7306/2020.4

A b s tr a c t. Majority of ca. 90 sites of sandstone crag groups and individual crags, occurring in the Świętokrzyskie (Holy Cross) Mts. region, represent the following crag-forming lithostratigraphic units: Cambrian Wiśniówka Formation, Devonian Barcza Fm and Zagórze Fm, Triassic Zagnańsk Fm and Krynki Beds, as well as Jurassic Sktoby Fm and Ostrowiec Fm. Specific features of these rocks are the occurrence of sandstone series, up to $20 \mathrm{~m}$ thick, above more plastic, clayey or heterolithic series, high-energy depositional environments, and siliceous composition. The crag-forming sandstones differ in the amount of siliceous cement: from strongly cemented Paleozoic quartzitic sandstones to porous Mesozoic sandstones with poor cement, which determines diverse mechanical properties. Strongly cemented Paleozoic rocks display high rock strength and abrasion resistance, while porous and theoretically friable Mesozoic sandstones are characterised by high grain packing due to compaction. Regarding the principal role of gravitational disintegration of rock massifs under the periglacial conditions in the Pleistocene, other factors constraining the crag formation and shaping are the tectonic situation of rocks (orientation of strata and joints), adequate joint spacing, and bed thickness. The interrelations between lithological and structural features of crag-forming sandstones and tectonics, conditioning erosion and weathering rates are specific for particular types of these sandstones.

Keywords: crags, sandstones, morphogenesis, lithology, tectonics, Świętokrzyskie Mts.

Wysteppowanie odsłoniętych powierzchni skalnych w Europie, w strefie klimatu umiarkowanego, jest ograniczone głównie do obszarów górskich. Natomiast na obszarach wyżyn i nizin europejskich skałki, jako elementy wypukłe w stosunku do otaczającej morfizjologii terenu, są rzadko występującymi elementami rzeźby. Są uznawane za formy reliktowe, powstałe w warunkach peryglacjalnych plejstocenu, choć uwarunkowane starszymi procesami głębokiego wietrzenia (Palmer, Radley, 1961; Tricart, Cailleux, 1972; Robinson, Williams, 1981; Alexandrowicz, 1990; Cílek i in., 2007; Young i in., 2009; Migoń i in., 2017; Duszyński i in., 2019). Skałki na tych obszarach istnieja jednak nadal i zagadnienie litologicznych, strukturalnych i tektonicznych uwarunkowań ich powstania oraz ewolucji nie zostało dotąd w pełni wyjaśnione. Rozwiązanie tego zagadnienia jest tym ciekawsze, że w Europie, za Robinsonem (2007), badamy nie tylko w jaki sposób właściwości litologiczno-strukturalno-tektoniczne decydują o kształcie form skałkowych, lecz zadajemy podstawowe pytanie dlaczego te formy w ogóle istnieją w zielonym, leśnym krajobrazie naszego kontynentu.

W przypadku Europy weryfikacji wymaga przede wszystkim teza, że istnienie form skałkowych jest warunkowane litologią i strukturą skały, zaś klimat jest drugorzędnym czynnikiem kształtującym morfologię obszarów skałkowych (Young i in., 2009). Wśród cech geologicznych warunkujących morfogenezę obszarów piaskowcowych wymienia się przede wszystkim porowatość skał (uziarnienie oraz ilość spoiwa), mineralogię (skład ziarnowy oraz spoiwo), uławicenie i spękania ciosowe, obecność wkładek ilastych oraz właściwości mechaniczne skał (np. Turkington, Paradise, 2005; Cílek i in., 2007; Young i in., 2009; Hall i in., 2012). Jednak wyniki badań charakte- ryzujących bezpośrednie powiązania pomiędzy cechami geologicznymi a istnieniem piaskowcowych form skałkowych w Europie (np. Robinson, Williams, 2005) były dotąd rzadko publikowane.

Region świętokrzyski jest dogodnym miejscem do prowadzenia badań cech warunkujących powstawanie form skałkowych, ponieważ na jego obszarze o wyżynnym typie rzeźby (Urban, 2014), podobnej ewolucji morfogenetycznej oraz zbliżonych warunkach klimatycznych występują skałki zbudowane z krzemionkowych skał klastycznych o różnej litologii i w różny sposób zaangażowanych tektonicznie. Jednak do początków tego wieku skałki świętokrzyskie praktycznie nie były przedmiotem badań. Jedyne hipotezy genetyczne dotyczyły najbardziej znanej grupy Skałek Piekło pod Niekłaniem, w przypadku której już Kuźniar (1923) sugerował eoliczne pochodzenie. Tezę tę rozwinął Lindner (1972, 1977), który uzasadniał ją specyficzną rzeźbą zachodniego zespołu skałek Piekła niekłańskiego oraz obecnością piaszczystych płatów po wschodniej, zawietrznej stronie płaskowzgórza zwieńczonego skałkami. Wiązał on powstanie skałek niekłańskich, ale także kilku innych grup skałkowych zachodniej części regionu świętokrzyskiego, z zachodnimi wiatrami lessotwórczymi okresu pessimum klimatycznego ostatniego zlodowacenia (Chlebowski, Lindner 1991). Publikacje Alexandrowicz (1990) oraz Alexandrowicz i Urbana (2005) dotyczyły raczej ochrony i waloryzacji skałek, niż zagadnień ich genezy i ewolucji.

Celem badań skałek świętokrzyskich, rozpoczętych w połowie lat 80. XX w. (Urban, 1986), jednak prowadzonych głównie w latach 2006-2010 było w szczególności: (a) wyjaśnienie w jaki sposób pozycja serii piaskowcowych w profilu litostratygraficznym, struktura piaskowców, 
ich skład mineralny, właściwości mechaniczne, gęstość spękań ciosowych oraz uławicenie, a także kierunki powierzchni uławicenia i ciosu wpływają na powstawanie oraz kształt form skałkowych; (b) rekonstrukcja procesów, które doprowadziły do powstania form skałkowych, czyli obnażenia i fragmentacji pakietów skał piaskowcowych; (c) wyjaśnienie w jaki sposób cechy wewnętrzne (litologia, struktura) oraz czynniki zewnętrzne decydują o rzeźbie powierzchni skałkowych. Szczegółowe wyniki tych badań ukazały się w ostatnich latach w angielskojęzycznych czasopismach o zasięgu międzynarodowym (Urban, 2015a, 2016; Urban i in., 2015; Urban, Górnik, 2017). W tym artykule zostały natomiast zebrane podstawowe wyniki tych badań i wnioski dotyczące czynników i procesów decydujących o rozwoju i ewolucji świętokrzyskich skałek piaskowcowych (pominięto wyniki badań uwarunkowań rzeźby powierzchni skałkowych).

\section{PRZEDMIOT BADAŃ - SKALKI ZBUDOWANE Z RÓŻNYCH PIASKOWCÓW SKAŁKOTWÓRCZYCH}

Przedmiotem badań były wszystkie znane stanowiska skałkowe regionu świętokrzyskiego (prawie 90), jak również wiele innych odsłonięć piaskowców wykorzystanych do obserwacji porównawczych (ryc. 1). Stanowiska skałkowe to najczęściej grupy skałek liczące od kilkunastu do ponad stu takich form, rzadziej pojedyncze formy skałkowe zbudowane z piaskowców paleozoicznych oraz mezozoicznych (nie uwzględniono nielicznych skałek utworzonych z piaskowców kredowych, jako nie leżących w granicach geologicznego regionu świętokrzyskiego). W skałkach, jak też $\mathrm{w}$ odsłonięciach piaskowców nietworzących skałek wykonano pomiary odległości oraz kierunków spękań ciosowych i powierzchni uławicenia, przeprowadzono badania petrograficzne (mikroskopowe), analizy porowatości, a także właściwości mechanicznych piaskowców (wytrzymałości na ściskanie i ścieralności na tarczy Boehmego). Wykorzystano ponadto materiały publikowane i archiwalne, w tym dokumentacje złóż, opracowania poszukiwawczo-złożowe itp. Badaniami zostały objęte również osady stokowe towarzyszące skałkom, w przypadku których analizowano uziarnienie, obtoczenie i skład petrograficzny ziarn, jak również wykonano datowania OSL i radiowegglowe. Ponadto zostały wykonane cztery profile tomografii elektrooporowej (ERT) wzdłuż stoków, na których występowały skałki. Ilość danych pomiarowych, sieggająca od kilkudziesięciu (niektóre właściwości mechaniczne) do kilku tysięcy (pomiary odległości ciosowych i ławicowych), pozwoliła na wykorzystywanie metod statystycznych (Urban, 2015a, 2016; Urban i in., 2015).

Podstawową zasadą metodyczną umożliwiającą określenie cech sprzyjających powstawaniu skałek było wyróżnienie jednostek litostratygraficznych, w których występuja piaskowce skałkotwórcze, oraz jednostek, w których piaskowce nie budują form skałkowych lub tworzą nieliczne i niewielkie tego typu formy. Do piaskowców skałkotwórczych zaliczono (ryc. 1,2):

1. piaskowce górnokambryjskiej formacji piaskowców z Wiśniówki, która tworzy najwyższe pasmo górskie Gór Świętokrzyskich, tzw. Pasmo Główne, stanowiące ciag pasm Klonowskiego, Łysogórskiego i Jeleniowskiego, z centralnym i najwyższym odcinkiem zwanym Łysogórami;

2. piaskowce dolnodewońskich formacji z Barczy oraz z Zagórza, budujących w północnej, łysogórskiej części trzonu paleozoicznego Gór Świętokrzyskich drugie w regionie pod względem wysokości Pasmo Klonowskie, występujące jednak również w południowej, kieleckiej części regionu;

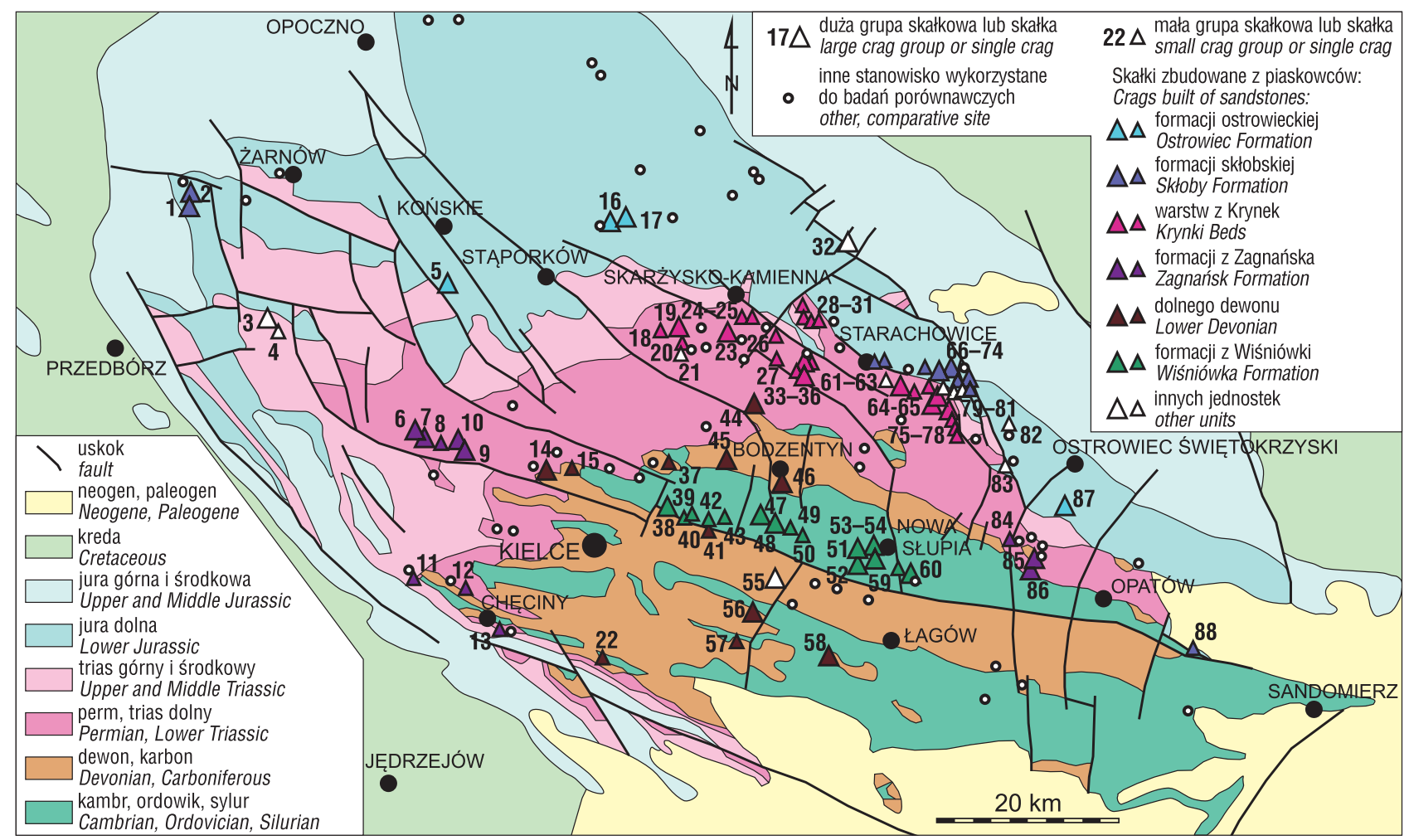

Ryc. 1. Lokalizacja stanowisk skałkowych na tle zgeneralizowanej mapy geologicznej regionu (mapa wg Urbana, 2014)

Fig. 1. Distribution of crag sites against the background of generalized geological map (map after Urban, 2014) 


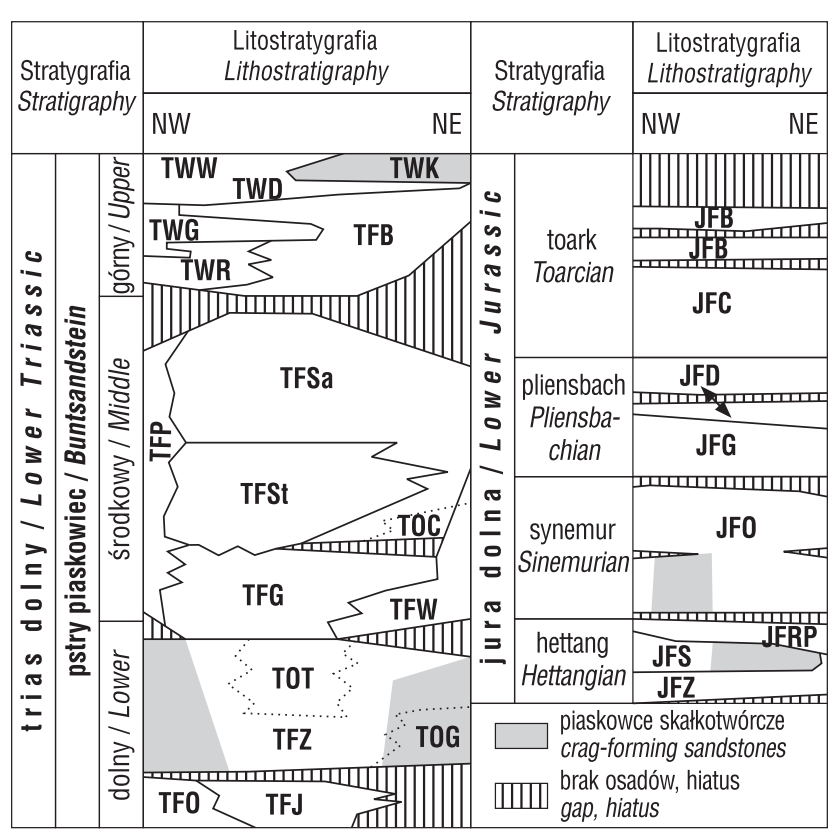

Ryc. 2. Pozycja piaskowców skałkotwórczych w profilach litostratygraficznych dolnego triasu oraz jury dolnej (litostratygrafia wg Pieńkowskiego, 2004; Kulety, Zbroi, 2006); objaśnienia skrótów: JFB - formacja borucicka, JFC - f. z Ciechocinka, JFD - f. drzewicka, JFG - f. gielniowska, JFO - f. ostrowiecka, JFRP - f. rudonośna z Przysuchy, JFS - f. skłobska, JFZ - f. zagajska, TFB - f. z Baranowa, TFG - f. z Goleniaw, TFJ - f. z Jaworznej, TFO - f. z Opoczna, TFP - f. z Piekoszowa, TFSa - f. z Samsonowa, TFSt - f. ze Stachury, TFW - f. z Wiór, TFZ - f. z Zagnańska, TOC - ogniwo z Cierchów, TOG - og. z Czerwonej Góry, TOT - og. z Tumlina, TWD - warstwy z Dalejowa, TWG - w. gipsowe, TWK w. z Krynek, TWR - w. z Radoszyc, TWW - w. z Wilczkowic

Fig. 2. Distribution of crag-forming sandstones in the lithostratigraphic sequences of Lower Triassic and Lower Jurassic ((lithostratigraphy after Pieńkowski, 2004; Kuleta, Zbroja, 2006); explanation of abbreviations: JFB - Borucice Formation, JFC Ciechocinek Fm, JFD - Drzewica Fm, JFG - Gielniów Fm, JFO Ostrowiec Fm, JFRP - Ore-bearing Przysucha Fm, JFS - Skłoby Fm, JFZ - Zagaje Fm, TFB - Baranów Fm, TFG - Goleniawy Fm, TFJ - Jaworzna Fm, TFO - Opoczno Fm, TFP - Piekoszów Fm, TFSa - Samsonów Fm, TFSt - Stachura Fm, TFW - Wióry Fm, TFZ - Zagnańsk Fm, TOC - Cierchy Member, TOG - Czerwona Góra M., TOT - Tumlin M., TWD - Dalejów Beds, TWG Gypsum Beds, TWK - Krynki Beds, TWR - Radoszyce Beds, TWW - Wilczkowice Beds

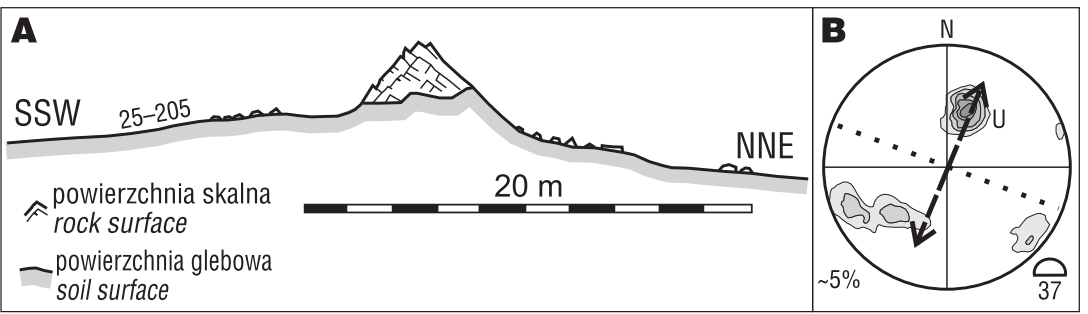

Ryc. 3. Widna Skałka. A-profil morfologiczny z zaznaczonym azymutem; B - diagram konturowy ciosu i uławicenia (odzwierciedlenie na płaszczyznę poziomą przecięć linii normalnych do mierzonych powierzchni z półkulą górną) z oznaczeniem ilości pomiarów (37) oraz odległości izolinii (ok. 5\%), spadkiem stoku (strzałki), rozciagłością grzbietu (linia kropkowana), U - upad warstw; $\mathbf{C}$ - skałka od strony wschodniej - patrz str. 146

Fig. 3. Widna Skałka. A - morphological profile with azimuth; B - contour diagram of joints and bedding planes (projection of normals to measured planes on the upper hemisphere reflected on horizontal surface) with number of measurements (37), isoline density (about 5\%), slope dip (arrows) and ridge stretching (dotted line), U - strata dip; C - crag from the east side - see p. 146
3. piaskowce dolnotriasowej (dolny pstry piaskowiec; induan) formacji z Zagnańska w zachodniej i północno-wschodniej części obrzeżenia permsko-mezozoicznego; natomiast form skałkowych w strefie, gdzie formacja ta reprezentowana jest przez ogniwo piaskowców z Tumli(ryc. 2); obrzeżenia, w rejonie doliny środkowego odcinka rzeki pónocnym odcinku obrzeżenia. nie Staporkowa i Końskich.

Świętokrzyskie skałki są niewielkie (o wysokości 4-6 m, maksymalnie $12 \mathrm{~m}$ ), ale zróżnicowane pod względem kształtu i sposobu występowania.

Górnokambryjskie piaskowce kwarcytowe formacji z Wiśniówki są zwykle, ale nie zawsze, wyraźnie uławicone, drobnoziarniste, bardzo zwięzłe i zlewne. Skałki zbudowane $\mathrm{z}$ tych piaskowców (15 stanowisk) tworza pojeedy (np. skałka Agata - nr 48, ryc. 1) (Urban, 2016) oraz nieregularne kopuły skalne (np. Wielki Kamień na Klonówce - nr 38, ryc. 1) (Urban, 2016) na grzbietach eregularne grzedy i progi na stokach górskich, niekiedy u ich podnóży. Przykładem grzbietowej skałki jest Widna Skałka (nr 50, ryc. 1) - grzęda arzbiecie Łysogór. Grzeda ma wysokość 1-4 m, długość $50 \mathrm{~m}$ i stanowi twardzielcową wychodnię kilku ławic piaskowców w obrębie wypłaszczenia grzbietowego pości rzedu $200 \mathrm{~m}$ (ryc. 3). Jedna ze ścian grzedy tworzą powierzchnie ławic, drugą, mniej regularną - czoła ławic wycięte wzdłuż gęstych spękań ciosowych. ưwiceniem, nierównoziarniste i czesto wykazujace przeone (zgodnie z zapadaniem warstw) stoły skalne na stojównież przygrzbietowe oraz grzbietowe ambony sa skałki na Bukowej Górze (nr 45, ryc. 1) (Urban, 2016) oraz grupa skałkowa Kamień Michniowski (nr 44, ryc. 1). Ta ostatnia jest złożona $\mathrm{z}$ kilkunastu skałek położonych na stromym stoku (ryc. 4A, B). Skałki w najwyższym pasie są reprezentowane przez progi (nr 1, 2, 3, 6, 15, 17, 18 na ryc. $4 \mathrm{~A})$, ambony (nr 5, 6, 7,14, 16, 19), ściany (nr $1,3,17)$ oraz nieregularne baszty skalne (nr 4, 16) o wysokości 2-8 m. Grupę największych skałek tworzą trzy ambony skalne (nr 5-7, ryc. 4A, B, C) zwieńczone basztą (nr 4) i ścianą skalną (nr 3). $\mathrm{W}$ pasie tym występują $\mathrm{w}$ większości formy in situ lub w niewielkim stopniu translacyjnie przemieszczone $(\mathrm{nr} 4,5)$. Wyjątkiem jest silnie zrotowana (w kierunku stoku) i obrócona wokół osi pionowej o ok. $70^{\circ}$ ambona (nr 6, ryc. 4A, B, C), pod którą utworzyła się najdłuższa w regionie jaskinia niekrasowa - Jaskinia Ponurego (Gubała i in., 1996). Poniżej tego pasa skałek występują mniejsze bloki skalne. 


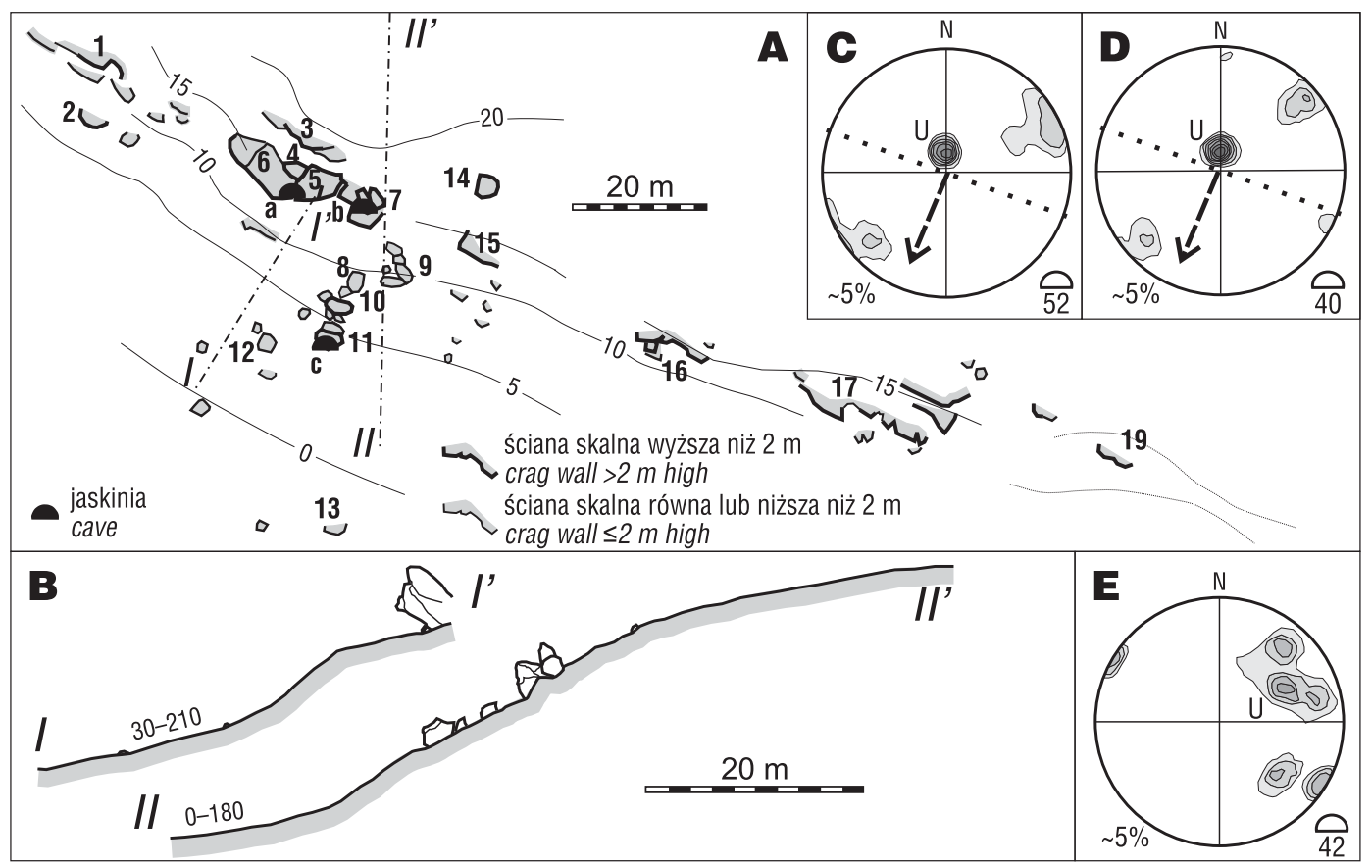

Ryc. 4. Skałki Kamień Michniowski. A - mapa skałek na tle orientacyjnej topografii; objaśnienia oznaczeń literowych - jaskinie: a - Jaskinia Ponurego, b - Szpara Alpinistów, c - Jama w Kamieniu; B - profile morfologiczne; C - diagram konturowy ciosu i uławicenia w skałce $\mathrm{nr} 3$ (in situ); $\mathbf{D}$-diagram konturowy ciosu i uławicenia w skałce $\mathrm{nr} 5$ (nieznacznie odsuniętej i prawoskrętnie zrotowanej); $\mathbf{E}$ - diagram konturowy ciosu i uławicenia w skałce nr 6; F - skałki nr 5 i 6 z otworem Jaskini Ponurego - patrz str. 146. Symbole, oznaczenia oraz skróty jak na ryc. 3

Fig. 4. Kamień Michniowski crag group. A - map of the group against approximated topography; explanations of letters - caves: a - Jaskinia Ponurego, b - Szpara Alpinistów, c - Jama w Kamieniu; B - morphological profiles; C - contour diagram of joints and bedding planes in crag No. 3 (in situ); D - contour diagram of joints and bedding planes in crag No. 5 (slightly moved and dextrally rotated); $\mathbf{E}$ - contour diagram of joints and bedding planes in crag No. 6. F - crags Nos. 5 and 6 with the entrances to the Jaskinia Ponurego - see p. 146. Symbols and abbreviations - see Fig. 3

Skałki zbudowane $\mathrm{z}$ dolnotriasowych piaskowców formacji z Zagnańska (11 stanowisk) występują w dwóch dużych grupach na Górze Perzowej: jednej obejmującej jej szczytowe partie i stok południowo-wschodni oraz drugiej - na stoku północnym (nr 9 i 10, ryc. 1). Grupy te są złożone $\mathrm{z}$ dużych i rozłożystych progów oraz bloków o kształtach stołów, płyt lub kopuł skalnych (Urban, 2015a). Piaskowce te tworzą także mniejsze grupy oraz pojedyncze formy skałkowe: grzędy, stoły, progi i baszty. Jedną z ciekawszych pod względem morfologii i litologii jest grupa skałek na wzniesieniu stanowiącym zachodnie przedłużenie Pasma Oblęgorskiego k. miejscowości Nowek-Biała Glina (nr 6, ryc. 1). Piaskowce budujące te skałki są wykształcone typowo dla utworów formacji z Zagnańska zachodniej części Pasma Oblęgorskiego: są gruboławicowe, nierówno- ziarniste, z domieszką kwarcowych otoczaków, silnie zsylifikowane (blasteza kwarcu, a także lokalna obecność cementów barytowych piaskowców w obrębie Pasma Oblęgorskiego może być związana z jego położeniem na linii uskoku świętokrzyskiego; Rubinowski, 1971). Natomiast sama grupa skałek ma oryginalną formę dwu grzęd schodzących po stokach sąsiadujących lokalnych kulminacji oraz ambony o wysokości do $3 \mathrm{~m}$. Większa grzęda jest silnie rozczłonkowana i złożona $\mathrm{z}$ elementów skalnych o bardzo różnych kształtach: baszt, form graniastosłupowych, murków (ryc. 5). Taki kształt skałek jest warunkowany nachyleniem warstw pod kątem $15^{\circ} \mathrm{w}$ kierunku północno-zachodnim oraz przede wszystkich bardzo gęstym ciosem rozcinającym poprzecznie grzędę (ryc. 5B).

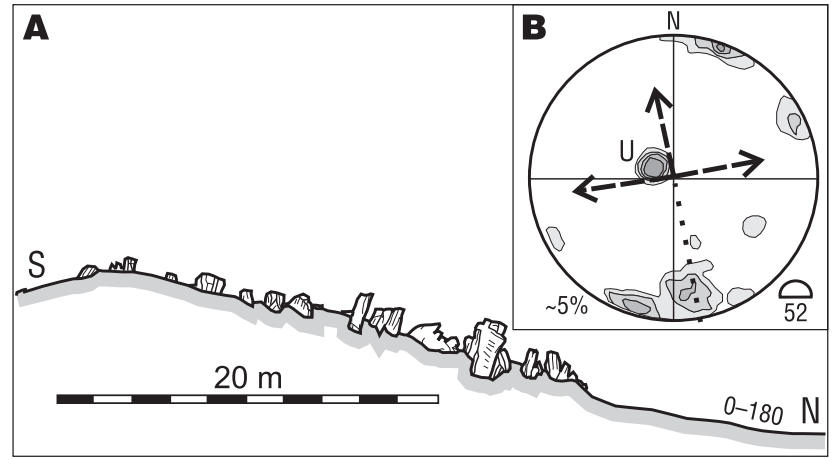

Ryc. 5. Skałki w stanowisku Nowek-Biała Glina. A - profil morfologiczny wzdłuż jednej $\mathrm{z}$ grzęd skalnych; B - diagram konturowy ciosu i uławicenia piaskowców w obrębie tej grzędy; C - środkowy fragment grzędy - patrz str. 146. Symbole, oznaczenia i skróty jak na ryc. 3

Fig. 5. Crag site Nowek-Biała Glina. A - morphological profile along the crag ridge; $\mathbf{B}$ - contour diagram of joints and bedding planes in the crag ridge; $\mathbf{C}$ - middle section of the crag ridge - see p. 146. Symbols and abbreviations - see Fig. 3

Piaskowce dolnotriasowych warstw z Krynek są średnioławicowe, ale nieregularnie uławicone, nierównoziarniste, z otoczakami kwarcu, z przekątnym warstwowaniem w różnej skali. Skałkotwórcze piaskowce dolnojurajskie są generalnie podobnie wykształcone, wykazują jednak mniejsze zróżnicowanie uziarnienia (brak otoczaków) oraz słabsze nachylenie laminacji wewnatrzławicowej. Skałki zbudowane z piaskowców warstw z Krynek (25 stanowisk) 
oraz piaskowców formacji skłobskiej (11 stanowisk) i ostrowieckiej (4 stanowiska) tworzą generalnie podobne do siebie grupy, złożone z przywierzchowinowych progów, ścian i ambon skalnych (rozczłonkowanych kuest), którym towarzyszą położone niżej na stoku, niekiedy bardzo liczne bloki o różnej wielkości i pokroju. Skałki zbudowane z piaskowców warstw z Krynek tworzą największą ilościowo, liczącą powyżej 100 form skałkowych, grupę skałek w rezerwacie Skaty w Krynkach (nr 75, ryc. 1) (Urban i in., 2015) i jego sąsiedztwie (nr 76-78), jak również trzy grupy skałkowe w Rudzie, położone po przeciwnej stronie doliny Kamiennej (nr 72-74) (Urban, 2016, 2019a). Liczne stanowiska skałkowe występują również w okolicach Skarżyska-Kamiennej, m.in. grupy skałkowe w Rejowie (nr 23, ryc. 1) (Urban i in., 2015; Urban, 2015b) oraz Piekło Dalejowskie (nr 19) (Urban, 2015a, 2017), a także praktycznie pojedyncze formy skałkowe, w tym tak unikatowe pod względem kształtu jak znana od dawna Brama Piekło
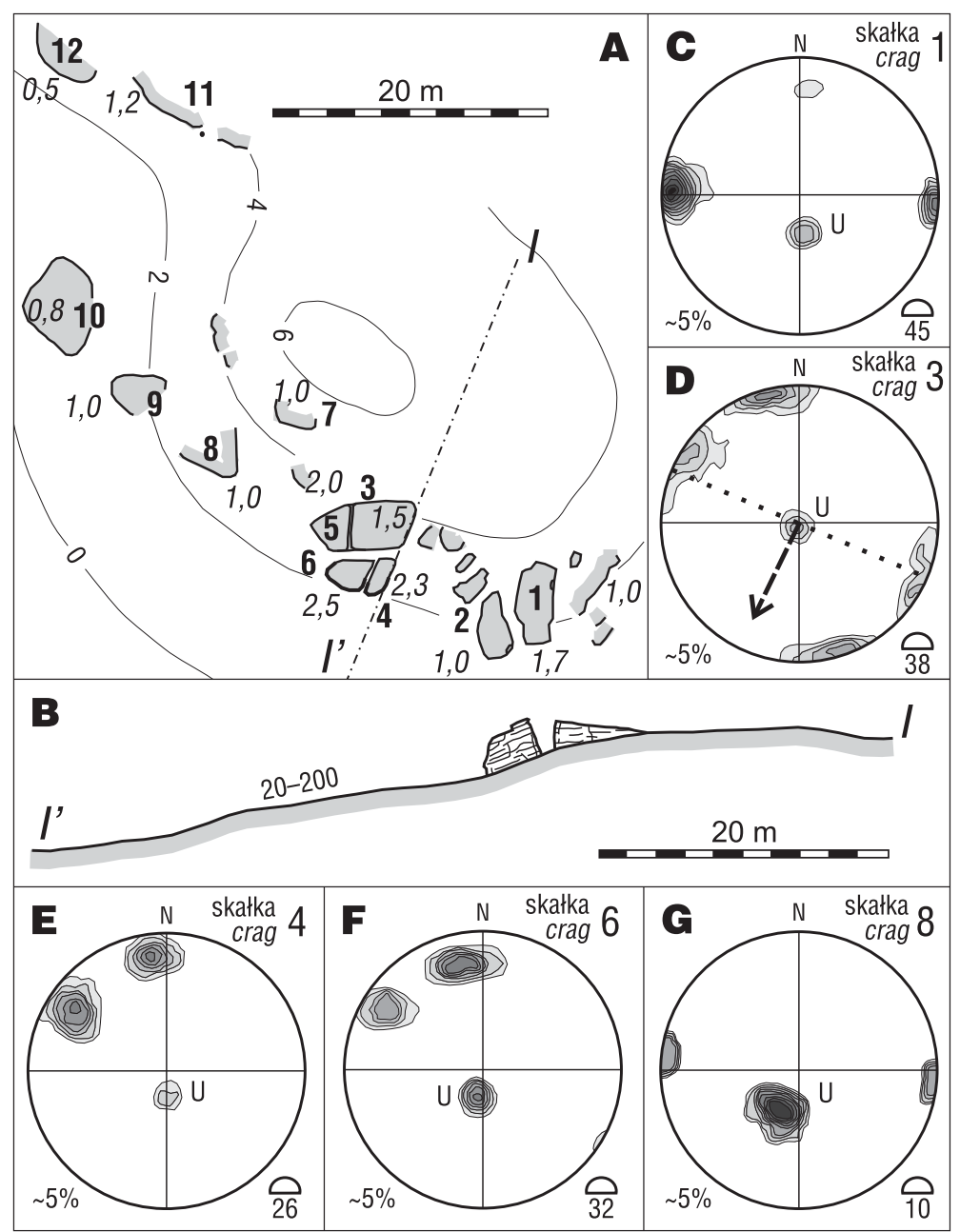

Ryc. 6. Skałki Biały Kamień. A - mapka największego, wschodniego zespołu skałek na tle orientacyjnej topografii; przy skałkach podano wysokości ścian; $\mathbf{B}$ - profil morfologiczny; $\mathbf{C}-\mathbf{G}$ - diagramy konturowe ciosu i uławicenia w wybranych skałkach, skałka nr 3 jest jedyną formą in situ wśród badanych form. H - skałki nr 3 i 4 - patrz str. 146; I - wschodnia część zespołu skałek ze skałkami 1 i 2 oraz występami skalnymi - patrz str. 146. Symbole, oznaczenia i skróty jak na ryc. 3 i 4

Fig. 6. Biały Kamień crag group. A - map of the largest sub-group against approximated topography; height of rock wall is given next to crag; $\mathbf{B}$ - morphological profile; $\mathbf{C}-\mathbf{G}$ - contour diagram of joints and bedding planes in the selected crags, crag No. 3 is the only in situ form among measured ones; $\mathbf{H}$-crags Nos. 3 and 4 - see p. 146; I - eastern part of the sub-group with crags Nos. 1 and 2 and smaller rock forms - see p. 146. Symbols and abbreviations - see Figs. 3 and 4 (nr 18) (Richling, 1938; Urban, Fijałkowska-Mader, 2018), czy skałki w lesie Pleśniówka (nr 30-32) (Urban, 2019b). Dobrym ich przykładem jest grupa skałkowa położona na południe od Parszowa, zwana Białym Kamieniem (nr 34, ( Charakterystyczna jej cechą są nieielkie deniwelacje terenowe (rzędu 3-5 m) i małe nachystokow $\left(5-15^{\circ}\right)$, na których skałki wystepuja w kilku (ac (ryc. 6A-D) z nich to bloki przesunięte w dól stoku oraz w różn spośb przechylone, najczęściej w kierunku spadku stoku (ryc. E-I).

Skałki zbudowane z piaskowców serii skłobskiej występują na wychodniach tej serii na stosunkowo krótkim odcinku północnego obrzeżenia doliny rzeki Kamiennej, stosunkowo liczne (ryc. 1). Największą grupą skałkową zbudowaną $\mathrm{z}$ tych piaskowców jest ciag skałek przywierzchowinowych w rezerwacie przyrody Skaty pod Adamowem i na jego przedłużeniu (nr 67, ryc. 1), mający długość ok. $1 \mathrm{~km}$ i złożony z prawie stu form skałkowych: ambon, progów i stołów (Urban, 2015a; Urban, Kasza, 2019). Pozostałe stanowiska to mniejsze grupy skałek najczęściej przywierzchowinowych o charakterze progów i ambon, niekiedy silnie podciętych, którym towarzyszą położone niżej na stoku bloki. Podobnie jak w przypadku wielu skałek zbudowanych $\mathrm{z}$ piaskowców triasowych, znaczna deniwelacja oraz duże nachylenie stoków nie są cechami koniecznymi dla występowania form skałkowych zbudowanych $\mathrm{z}$ piaskowców formacji skłobskiej. Dobrym przykładem ilustrującym cechy skałek zbudowanych z piaskowców dolnojurajskich jest grupa skałkowa Adamów-Północ (nr 66, ryc. 1 i 7) (Urban, 2015a) położona w górnej części doliny Ruśni, w której jest także zlokalizowany rezerwat Skaty pod Adamowem. Grupę tę tworzy niezbyt wybitna, rozczłonkowana kuesta wyznaczająca wychodnię pakietu skałkotwórczego (skałki nr 3, 5, 7, 12, 13, 16, 21, ryc. 7A, D) oraz oderwane i odsunięte od niego bloki, pochylone w kierunku spadku stoku (ryc. 7A-C, E-G).

Skałki zbudowane z piaskowców dolnojurajskich formacji ostrowieckiej są reprezentowane przez trzy grupy skałkowe położone w granicach Garbu Gielniowskiego, w tym dwie w okolicach Niekłania: grupę w rezerwacie Skałki Piekło pod Niekłaniem oraz mniejszą grupę zlokalizowaną ok. $0,5 \mathrm{~km}$ na północny zachód od tego rezerwatu. To pierwsze stanowisko jest najbardziej znaną grupą skałkową regionu świętokrzyskiego, opisywaną od dawna (Massalski, Kaznowski, 1928; Lindner 1972, 1977; Alexandrowicz i in., 1975; Alexandrowicz, 1990; Urban, 1996), która ostatnio także była przedmiotem szczegółowej analizy geomorfologicznej (Urban i in., 2015; Urban i in., 2019). Trzecią grupę stanowią skałki Piekło k. Gatników również od dawna znane i chronione jako pomnik przyrody (Alexandrowicz i in., 1975). Czwartą skałką zbudowaną z piaskowców formacji ostrowieckiej, położoną jed- 


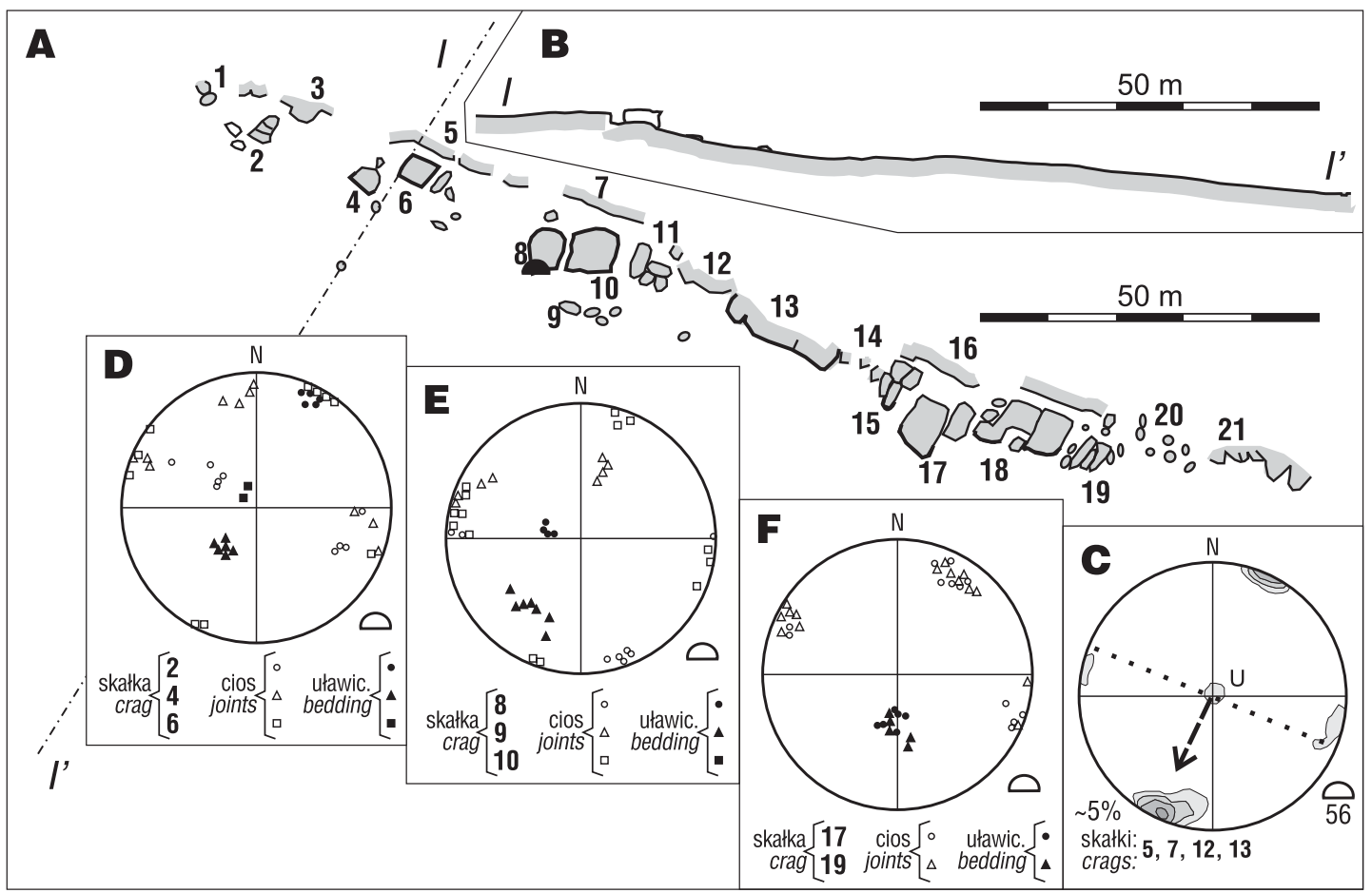

Ryc. 7. Grupa skałkowa Adamów-Północ. A - mapa grupy skałkowej; B - profil morfologiczny; C - diagram konturowy ciosu i uławicenia skałek in situ; D-F-diagramy punktowe ciosu i uławicenia w wybranych skałkach ex situ (blokach); G - skałka nr 6, widoczna na profilu - patrz str. 146. Symbole, oznaczenia i skróty jak na ryc. 3 i 4 Fig. 7. Adamów-Północ crag group. A - map of the group; $\mathbf{B}$ - morphological profile; $\mathbf{C}$ - contour diagram of joints and bedding planes in the crags in situ. $\mathbf{D}-\mathbf{F}$ - pole points diagrams of joints and bedding planes in the selected crags. $\mathbf{G}-$ crag No. 6, visible on the profile - see p. 146. Symbols and abbreviations - see Figs. 3 and 4

nak w zupełnie innej, wschodniej części północnego obrzeżenia permsko-mezozoicznego Gór Świętokrzyskich jest Sfinks w Szewnej k. Ostrowca Świętokrzyskiego, opisywany także już w pierwszej połowie XX w. (Massalski, 1936).

\section{LITOLOGIA, CECHY STRUKTURALNE I WLAŚCIWOŚCI FIZYCZNO-MECHANICZNE PIASKOWCÓW SKAŁKOTWÓRCZYCH}

Cechami litologicznymi typowymi dla piaskowców tworzących piaskowcowe skałki w regionie świętokrzyskim są: (i) występowanie pakietów piaskowców skałkotwórczych w sekwencjach geologicznych o dużej zmienności litologicznej, (ii) wysokoenergetyczne warunki sedymentacji, a także (iii) krzemionkowy skład zarówno szkieletu ziarnowego, jak i spoiwa (Urban, 2016). Opisy formacji geologicznych, w których występują piaskowce skałkotwórcze, dane archiwalne (profile otworów wiertniczych), obserwacje terenowe (np. notowane w sąsiedztwie skałek ślady podziemnego górnictwa pokładowych rud żelaza w seriach ilasto-marglistych), jak również wyniki badań geofizycznych (np. Kowalczewski i in., 1989; Kowalczewski, 2000), w tym profilowania metodą ERT wykonane w czterech stanowiskach skałkowych (ryc. 8) (Urban i in., 2015), wskazują, że serie piaskowców skałkotwórczych mają miąższość od kilku do ok. $20 \mathrm{~m}$ i są przewarstwione seriami ilastymi, mułowcowymi lub heterolitycznymi. Udział piaskowców w profilach obu skałkotwórczych formacji dolnojurajskich nie przekracza $38 \%$ i jest zbliżony do udziału tych skał w innych formacjach dolnojurajskich (Kozydra, 1968). Wyższy udział piaskowców można oszacować na podstawie danych otworowych w przypadku tria-

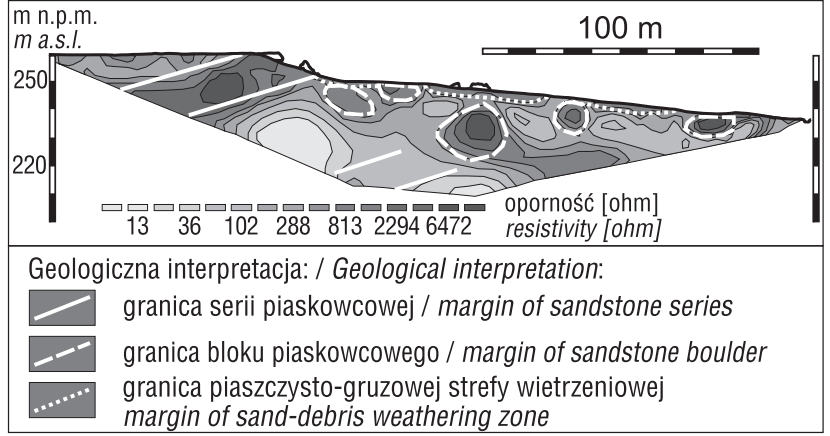

Ryc. 8. Profil elektrooporowy wykonany metodą ERT, przecinający ciagg skałek zbudowanych z piaskowców formacji skłobskiej stanowiska Skaty pod Adamowem (wg Urbana i in., 2015)

Fig. 8. Electro-resistivity transect (ERT image) crossing crag line (built of sandstones of the Skłoby Fm) of Skaty pod Adamowem site (after Urban et al., 2015)

sowych formacji z Zagnańska (82\%) oraz warstw z Krynek (65\%) (Urban, 2016).

W przypadku skałkotwórczych piaskowców dewonskich, triasowych i jurajskich wysokoenergetyczne warunki sedymentacji mają odzwierciedlenie w specyficznych strukturach skał, takich jak: nieregularne uławicenie i brak wkładek ilastych lub mułowcowych, nierówne uziarnienie (w przypadku piaskowców dewońskich oraz triasowych lokalnie obecność otoczaków kwarcowych) i przekątna laminacja (Teofilak-Maliszewska, 1968; Senkowiczowa, 1970; Łobanowski, 1990; Trela, 1999; Pieńkowski, 2004; Guzik, 2017). Charakterystyczny jest np. brak skałek w zachodnim odcinku wychodni formacji ostrowieckiej, w którym piaskowce tej formacji są często cienkoławicowe i prze- 
warstwione wkładkami drobnoziarnistymi: mułowcowymi lub iłowcowymi. Pewną odmienność w tym zakresie wykazują drobnoziarniste i bardzo drobnoziarniste kambryjskie piaskowce formacji z Wiśniówki, które są także uznawane za osady środowisk wysokoenergetycznych, choć środowiska te są różnie definiowane (Malec, 2004 głębokomorskie środowisko prądów zawiesinowych; Jaworowski, Sikorska, 2006 - środowisko płytkomorskie).

Bardzo charakterystyczną cechą piaskowców skałkotwórczych, zdecydowanie odróżniająca je od innych piaskowców, jest prawie wyłącznie krzemionkowy skład mineralny. W sensie petrograficznym piaskowce te są najczęściej arenitami kwarcowymi, rzadziej (w przypadku piaskowców formacji barczańskiej) arenitami sublitycznymi lub subarkozowymi. Jedynie piaskowce formacji z Zagnańska

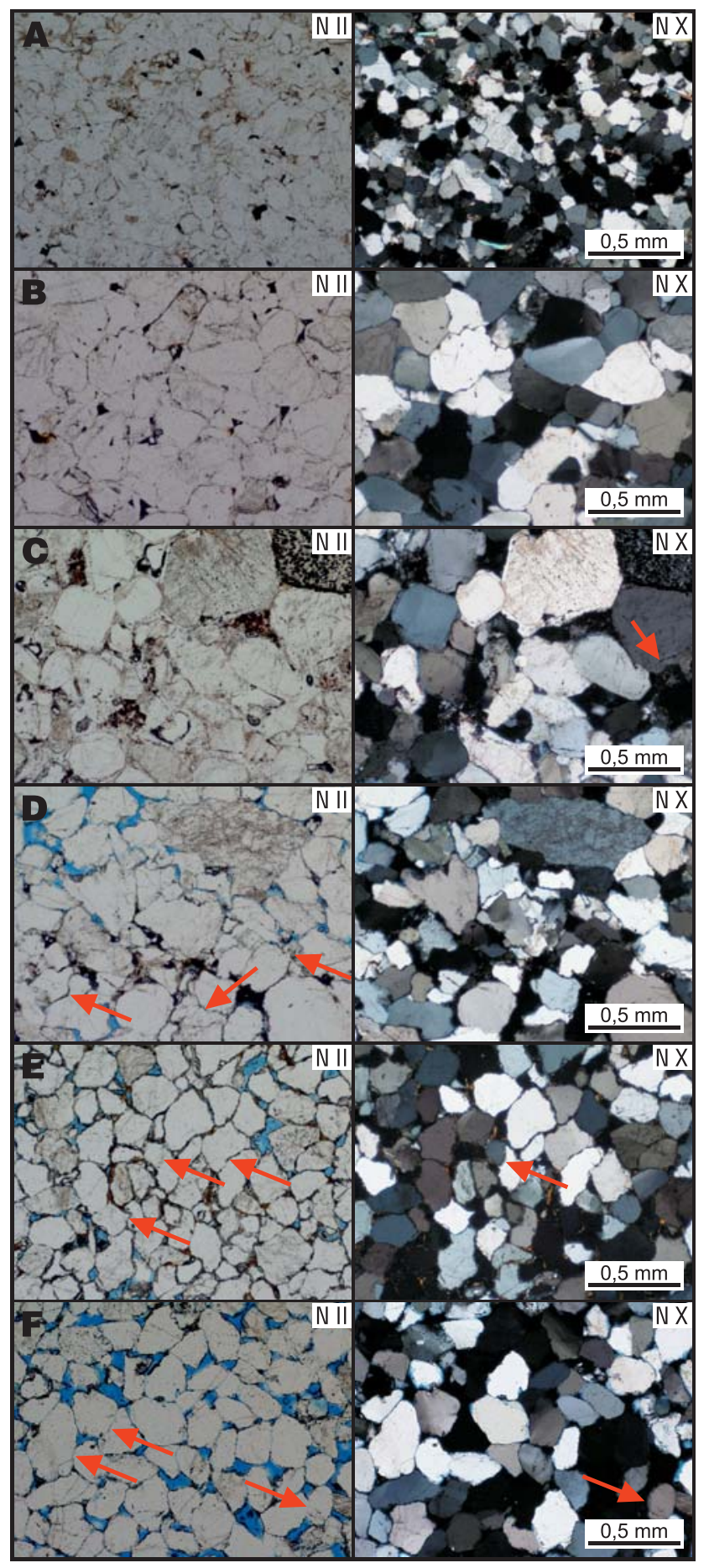

wykazują słabszą dojrzałość mineralogiczną i są klasyfikowane zazwyczaj jako arenity sublityczne lub lityczne (zawierające jednak głównie ziarna krzemionkowe), lokalnie szarowaki. Krzemionkowe jest również spoiwo piaskowców, którego ilość jest jednak bardzo różna w zależności od formacji (Teofilak-Maliszewska, 1968; Peszat, 1973; Kuleta, 1976, 1981, 1985, 2004; Barczuk, 1979; Rubinowski i in., 1986; Łobanowski, 1990; Urban, 2016).

W przypadku piaskowców formacji z Wiśniówki oraz piaskowców dewońskich spoiwo jest wypełniające, skrystalizowane, ziarna są obrośnięte syntaksjalnym kwarcem, często trudnym do odróżnienia od szkieletu, choć w przypadku piaskowców dewońskich stopień rekrystalizacji i wypełnienia przestrzeni międzyziarnowej bywa lokalnie mniej zaawansowany (ryc. 9). Piaskowce o krzemionkowym szkielecie ziarnowym i bazalnym cemencie cechują się oczywiście bardzo niską porowatością (ryc. 10) (Peszat, 1973; Rubinowski i in., 1986; Kowalczewski i in., 1989; Sikorska, 2000; Urban, 2016).

Stopień wypełnienia przestrzeni międzyziarnowej kwarcem w triasowych piaskowcach formacji z Zagnańska jest zróżnicowany. Badania autorskie (Urban, 2016) oraz dane literaturowe (Barczuk, 1979; Rubinowski, 1971; Kuleta, 1976, 1985, 2004; Gagol i in., 2005) sugerują, że jest on największy w strefie bliskiej przebiegowi głównej dyslokacji świętokrzyskiej, a więc tam gdzie występują formy skałkowe Pasma Oblęgorskiego. Natomiast w nietworzących skałek piaskowcach eolicznych ogniwa z Tumlina, występujących w środkowej części północnego obrzeżenia, istotnym składnikiem spoiwa są tlenki żelaza tworzące sieć żyłek pomiędzy ziarnami. Piaskowce warstw z Krynek oraz formacji skłobskiej i ostrowieckiej są bardzo ubogie w cement, ich spoiwo kontaktowe jest praktycznie wyłącznie krzemionkowe (stąd też Barczuk, 1979, nazywa piaskowce warstw z Krynek piaskowcami kwarcytowymi). W konsekwencji piaskowce te mają znacznie większy udział pustej przestrzeni międzyziarnowej, który w badaniach planimetrycznych sięga od kilku do kilkunastu procent (szczegółowe dane: Urban, 2016). W piaskowcach skałkotwórczych ziarna są jednak bardzo gęsto upakowane, na co

\section{$\leftarrow$}

Ryc. 9. Obrazy mikroskopowe wybranych typów piaskowców; barwa niebieska w obrazie piaskowców mezozoicznych oznacza pustą przestrzeń międzyziarnową, czerwone strzałki wskazują wybrane kontakty wklęsło-wypukłe, suturowe lub zabliźnione. A - kambryjski piaskowiec ze skałki na Górze Jeleniowskiej (nr 60, ryc. 1); B - dewoński piaskowiec ze skałek na Bukowej Górze (nr 45); C - triasowy piaskowiec formacji z Zagnańska ze stanowiska Nowek-Biała Glina (nr 6); D - triasowy piaskowiec warstw z Krynek grupy skałkowej Biały Kamień (nr 34). E - jurajski piaskowiec formacji skłobskiej ze Skatek pod Adamowem (nr 67); F - jurajski piaskowiec formacji ostrowieckiej z Piekła Niektańskiego (nr 17)

Fig. 9. Microscopic images of crag-forming sandstones; blue colour in Mesozoic sandstone images marks intergranular space, red arrows point at selected concave-convex, sutured and healed contacts. A - Cambrian sandstone from Góra Jeleniowska site (No. 60, Fig. 1); B - Devonian sandstone from Bukowa Góra site (No. 45). C - Triassic sandstone of the Zagnańsk Fm from Nowek-Biała Glina site (No. 6). D - Triassic sandstone of the Krynki Beds from Biały Kamień crag group (No. 34); E - Jurassic sandstone of Skłoby Fm from Skatki pod Adamowem crag group (No. 67); F - Jurasic sandstone of the Ostrowiec Fm from Piekto pod Niektaniem crag group (No. 17). 


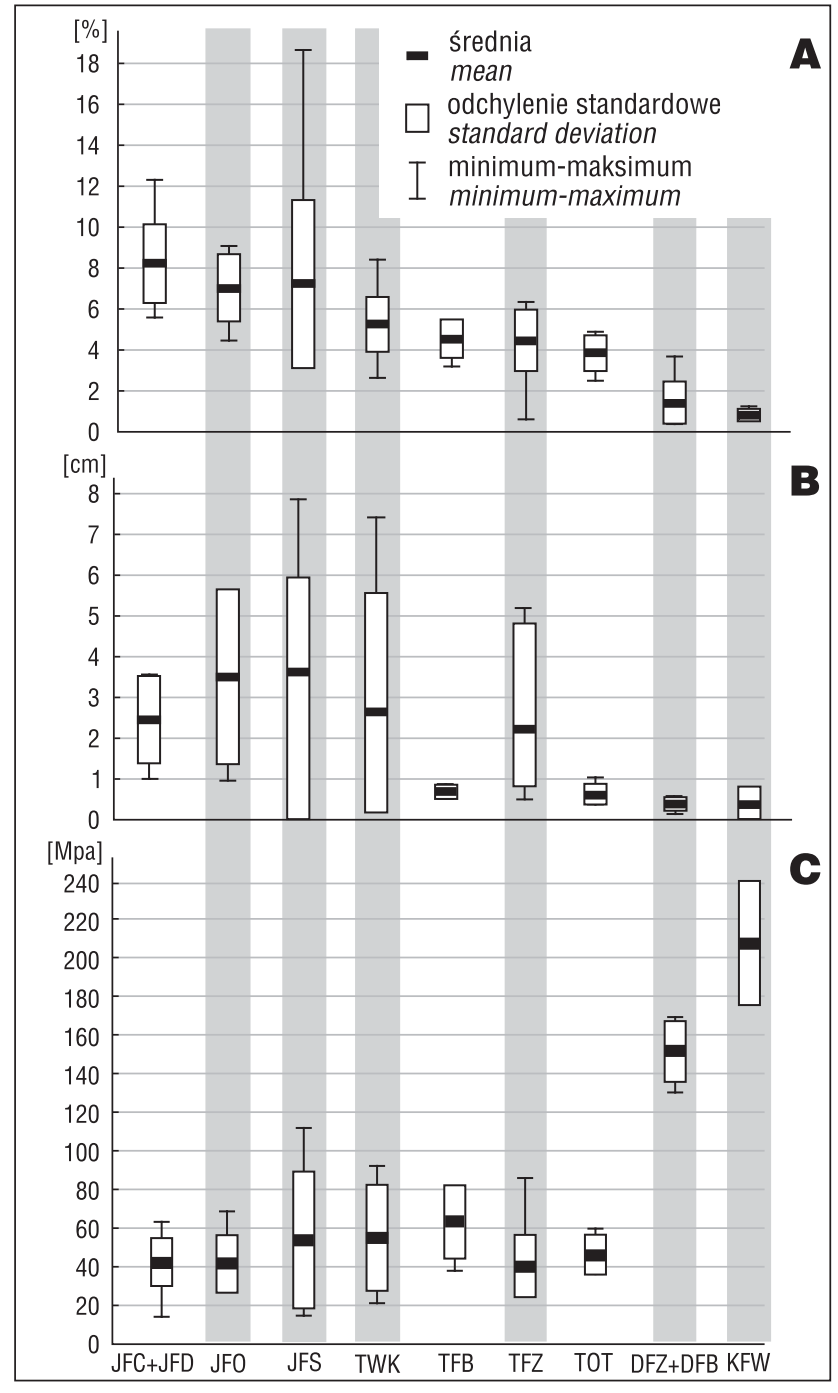

Ryc. 10. Nasiąkliwość wagowa (A), ścieralność na tarczy Boehmego (B) oraz wytrzymałość na ściskanie na sucho (C) piaskowców świętokrzyskich z różnych jednostek litostratygraficznych: wartości średnie, odchylenie standardowe oraz wartości maksymalne i minimalne; symbole jednostek litostratygraficznych - patrz ryc. 2 oraz: DBF - dewon, formacja barczańska, DZF dewon, formacja zagórzańska, KFW - kambr, formacja piaskowców z Wiśniówki (wg Urbana, 2016)

Fig. 10. Water absorption (A), abrasion resistance $(\mathbf{B})$ and dry compressive rock strength $(\mathbf{C})$ of sandstones from various lithostratigraphic units of the Swiętokrzyskie Mts.: arithmetic means, standard deviations and extreme values; symbols - see Fig. 2 and as follows: DBF - Devonian, Barcza Fm, DZF - Devonian, Zagórze Fm, KFW - Cambrian, Wiśniówka Sandstone Fm (after Urban, 2016)

wskazują ich kontakty, które są często wklęsło-wypukłe lub zazębiające się, a nawet suturowe (ryc. 9). W świetle założeń Houseknechta (1987, 1989), że pierwotna przestrzeń międzyziarnowa wynosi nie mniej niż 30\%, kompakcja chemiczna w mezozoicznych piaskowcach skałkotwórczych zmniejszyła objętość tej przestrzeni o 30-50\% (Urban, 2016). Podczas analizy piaskowców formacji skłobskiej Teofilak-Maliszewska (1968) napisała Jedna z przyczyn zwięzłości opisywanych piaskowców, poza obecnościq opalu, jest także niezwykle szczelne ułożenie kwarcu w skale. Szeregu próbek nie udało się rozdrobnić mimo kilkutygodniowego gotowania ich $w \mathrm{HCl}$ z siarczanami. Podobną opinię wyraziła Kobylec (2008), która stwierdziła, że piaskowce formacji skłobskiej charaktery- zuja się najwyższym stopniem upakowania materiału okruchowego. Niską porowatość piaskowców spagowej części profilu dolnej jury w środkowej Polsce, niższą niż w wyższych częściach tego profilu, stwierdziły też Kozłowska i Kuberska (2014).

Właściwości fizyczno-mechaniczne piaskowców mezozoicznych znacznie różnią się od właściwości skał paleozoicznych. Piaskowce te należą do grupy skał o średniej lub słabej wytrzymałości na ściskanie (dla poszczególnych formacji wartość ta mieści się średnio w granicach 40,5-54,8 MPa) oraz średniej, dużej lub bardzo dużej ścieralności na tarczy Boehmego (średnio 2,8-4,3 cm) (ryc. 10) (Urban, 2016; por. Peszat, 1973; Guzik, 2017).

W przypadku skał paleozoicznych wysoka odporność na wietrzenie i erozję - i w konsekwencji, trwałość oraz stabilność ścian skalnych odsłoniętych na powierzchni jest warunkowana dużą ilością spoiwa krzemionkowego i wyrażona odpowiednimi parametrami fizyczno-mechanicznymi. Z kolei w przypadku piaskowców mezozoicznych cechą decydującą o wytrzymałości na wietrzenie jest kohezja spowodowana bardzo gęstym upakowaniem ziarn oraz ich cementacją niemal wyłącznie krzemionką. Stopień upakowania oraz krzemionkowy charakter spoiwa, jak również skład litologiczny (brak wkładek ilastych) odróżnia mezozoiczne piaskowce skałkotwórcze od piaskowców podobnego wieku nietworzących skałek. Triasowe piaskowce formacji z Zagnańska zajmują pozycję pośrednią pomiędzy piaskowcami paleozoicznymi a młodszymi piaskowcami mezozoicznymi: $\mathrm{z}$ jednej strony mają więcej spoiwa krzemionkowego niż inne piaskowce mezozoiczne, z drugiej - także ich szkielet ziarnowy jest silnie upakowany (Urban, 2016).

Analiza porównawcza, dokonana na podstawie danych z wielu opracowań publikowanych i archiwalnych (Teofilak-Maliszewska, 1968; Kuleta, 1976, 1985, 2004; Barczuk, 1979; Kuleta, Nawrocki, 2000; Pieńkowski, 2004; Gagol i in., 2005; Kuleta, Zbroja, 2006; Kobylec 2008; Kozłowska, Kuberska, 2014; Guzik, 2017) oraz własnych danych, wykazuje, że piaskowce dolnotriasowe i dolnojurajskie nietworzące skałek (także formacji skałkotwórczych w innych lokalizacjach - por. Guzik, 2017) cechuja się mniejszą dojrzałością petrograficzną i większą zmiennością mineralogiczną. W ich składzie ziarnowym występują, obok kwarcu, różne minerały (skalenie, miki) i skały (w tym węglanowe) zaś w spoiwie - tlenki żelaza, minerały ilaste, węglanowe lub/i siarczanowe. Kompakcja tych skał jest mniejsza niż piaskowców skałkotwórczych (planimetryczny udział przestrzeni międzyziarnowej przekracza często 20\% - Urban, 2016), zaś nasiąkliwość wagowa jest bardzo zróżnicowana, sięgając kilkunastu procent. Parametry mechaniczne piaskowców, które nie tworzą skałek, nie różnią się zasadniczo od tych parametrów określonych dla piaskowców skałkotwórczych, mieszcząc się w grupie średnich i niskich wartości wytrzymałości na ściskanie (w przypadku piaskowców formacji z Baranowa nawet wyższych niż dla mezozoicznych piaskowców skałkotwórczych) oraz średnich i wysokich ścieralności (szczegółowe dane: Urban, 2016).

Piaskowce wielu skałkotwórczych regionów Europy, podobnie jak na obszarze świętokrzyskim, powstały w środowiskach wysokoenergetycznych. W obrębie czeskiej niecki kredowej piaskowce skałkotwórcze stanowią osady stożków deltowych. Deltową genezę mają też karbońskie piaskowce skałkotwórcze Fell i Millstone Grit Sandstones w Wielkiej Brytanii. Piaskowce skałkotwórcze Lotaryngii 
powstawały w płytkiej strefie basenu szelfowego. Piaskowce Karpat zewnętrznych stanowią osady prądów podmorskich (Alexandrowicz, 1978, 1990; Colbach, 2005; Robinson, Williams, 2005; Robinson, 2007; Sandstone..., 2007; Wojewoda i in., 2011; Adamovič i in., 2015). Przegląd piaskowcowych regionów świata wskazuje, że obecność wkładek ilastych i uniemożliwia formowanie jednolitych ścian skalnych (Young i in., 2009).

Miąższość warstw oraz odległość (gęstość) spękań ciosowych są istotnymi cechami warunkującymi powstawanie oraz kształt form skałkowych. Świadczą o tym różnice wielkości tych parametrów pomiędzy piaskowcami skałkotwórczymi a innym piaskowcami w regionie (ryc. 11).

Piaskowce kambryjskie budujące skałki Pasma Łysogórskiego są płytowe, o średniej grubości warstw, wahającej się $\mathrm{w}$ granicach $0,3-0,6 \mathrm{~m}$. Natomiast piaskowce tworzące Wielki Kamień na Klonówce (nr 38, ryc. 1) oraz skałkę na Górze Jeleniowskiej (nr 60) wykazują bardzo różną grubość warstw. Piaskowce dewońskie są zazwyczaj gruboławicowe, ale znaczna jest też zmienność tego parametru w poszczególnych stanowiskach (ryc. 11A). Triasowe piaskowce formacji z Zagnańska, które występują w formach skałkowych są stosunkowo gruboławicowe. Średnia grubość ławic waha się w poszczególnych stanowiskach od 0,9 m do 2,1 m. Piaskowce warstw z Krynek cechują się nieregularnym, często nieciagłym uwarstwieniem; powierzchnie poziomej oddzielności ulegają częstej amalgamacji, stąd też grubość warstw wykazuje duże wahania. Przekracza ona we wszystkich stanowiskach skałkowych, z wyjątkiem Cygańskiej Kapy (nr 36, ryc. 1), wartość $0,5 \mathrm{~m}$, ale sięga nawet $2 \mathrm{~m}$, co daje średnią $0,9 \mathrm{~m}$. Piaskowce skałkotwórcze formacji skłobskiej i formacji ostrowieckiej wykazują nieco większą regularność oddzielności ławicowej niż piaskowce warstw z Krynek. Przy średnich grubościach ławic w poszczególnych stanowiskach rzędu 0,9-1,5 m, średnie dla obu populacji są takie same i wynoszą 1,1 m (ryc. 11A) (Urban, 2016).

Pod względem charakteru spękań znowu wyróżniaja się piaskowce kambryjskie, które są pocięte wieloma zespołami spękań ciosowych, przecinających się pod różnymi kątami. Część tych spękań jest wtórnie zabliźniona kwarcem i nie spełnia już roli powierzchni nieciagłości. Generalnie jednak piaskowce te cechują się znaczną gęstością spękaniowych powierzchni oddzielności. W większości stanowisk skałkowych zbudowanych z tych piaskowców średnie odległości ciosowe są niższe lub bliskie $1 \mathrm{~m}$ (najniższa - 0,4 m), jedynie w przypadku Wielkiego Kamienia na Klonowce (nr 38, ryc. 1) średnia odległość spękań sięga $2,1 \mathrm{~m}$. Skałkotwórcze piaskowce dewońskie oraz mezozoiczne charakteryzują się występowaniem regularnego systemu ciosowego, złożonego $\mathrm{z}$ dwu zespołów ciosu katetalnego, najczęściej ortogonalnego, w przypadku niektórych stanowisk piaskowców dewońskich (Bukowa Góra - nr 45, ryc. 1) drabinowego. W przypadku piaskowców dewońskich średnie odległości ciosowe w poszczególnych stanowiskach są bardzo zróżnicowane - 1,1-4,0 m, przy maksymalnych odległościach sięgających $8,0 \mathrm{~m}$, zaś średnia dla całej populacji wynosi prawie $2,0 \mathrm{~m}$ (ryc. 11B). Skałkotwórcze piaskowce triasowe formacji z Zagnańska także cechują się znacznym zróżnicowaniem gęstości ciosu pomiędzy stanowiskami - skrajne wartości tego parametru wahają się od $0,2 \mathrm{~m}$ do $9,8 \mathrm{~m}$, średnie w poszczególnych stanowiskach - 0,6-4,1 m, zaś średnia dla całej populacji (i obu zespołów) wynosi $2,9 \mathrm{~m}$ (ryc. 11B). Dwukrotnie mniejszą gęstość ciosu obserwuje się w skałkach
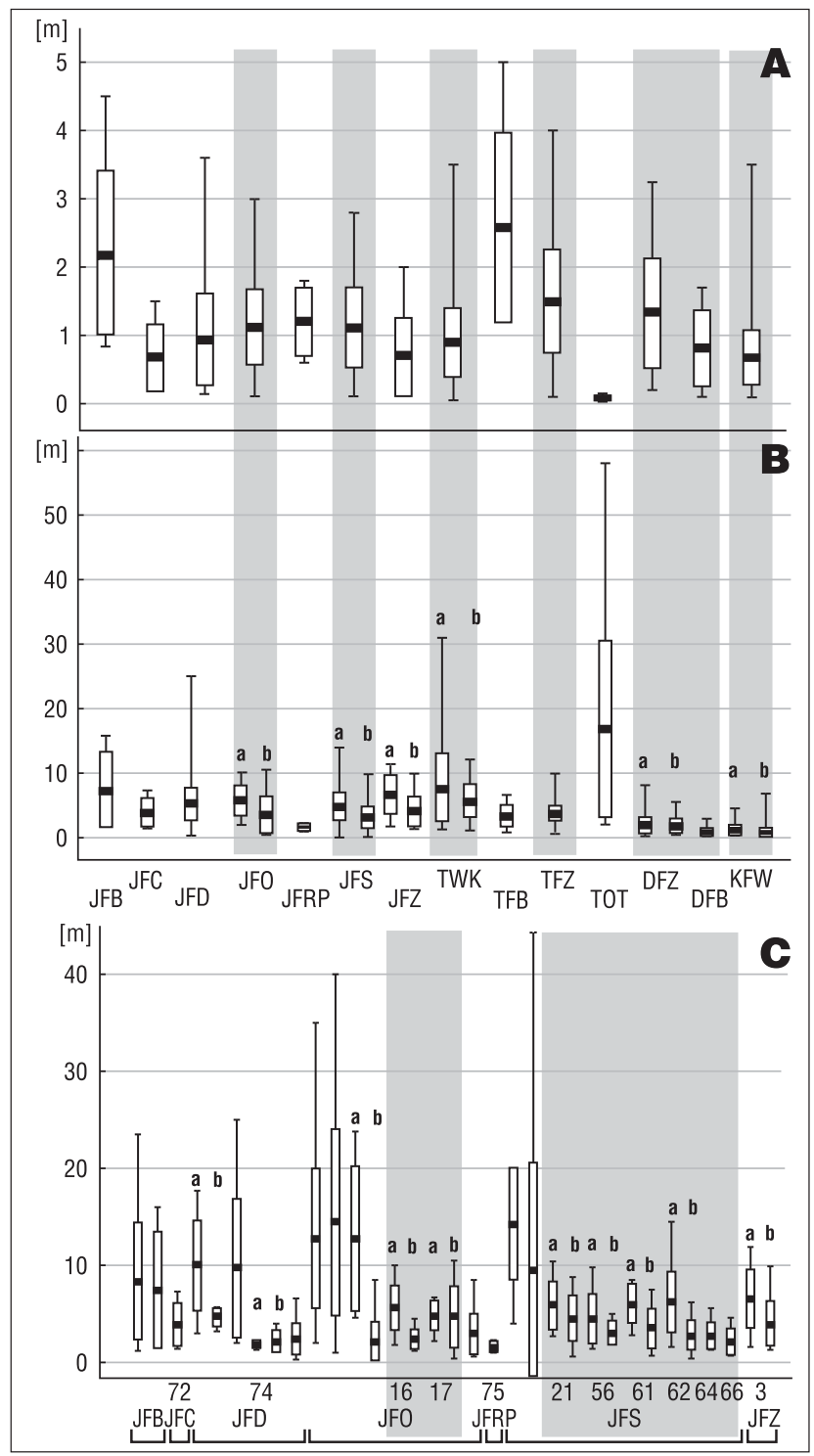

Ryc. 11. Miąższość ławic (A) oraz gęstość ciosu wyrażona odległością spękań ciosowych (B) w piaskowcach świętokrzyskich z różnych jednostek litostratygraficznych, a także gęstość ciosu w stanowiskach piaskowców jurajskich $(\mathbf{C})$ : wartość średnia, odchylenie standardowe (A, B - średnie w stanowiskach) oraz wartość maksymalna i minimalna; symbole - patrz ryc. 2 i 10 ; na ryc. C podano numery stanowisk skałkowych; dla większości jednostek pomierzono osobno odległości ciosowe rzadszego (a) oraz gęstszego zespołu ciosu (b) (wg Urbana, 2016, znacznie zweryfikowane)

Fig. 11. Bed thickness (A) and joint spacing (B) of sandstone from various lithostratigraphic units of the Świętokrzyskie Mts., as well as joint spacing in the sites of Jurassic sandstones (C): arithmetic mean, standard deviation (average for the sites) and extreme values; symbols - see Fig. 2 and 10; in Figure C, numbers of crag sites are given; for most units, a more spacious joint set (a) was measured separately from the more dense one (b (after Urban, 2016, greatly verified)

zbudowanych z piaskowców warstw z Krynek, w przypadku których cecha ta jest także stosunkowo najmniej zróżnicowana. Średnie odległości ciosu w stanowiskach skał- kowych tych piaskowców wahają się pomiędzy $3,3 \mathrm{~m}$ a $11,2 \mathrm{~m}$, podczas gdy średnia dla obu zespołów wynosi $6,5 \mathrm{~m}$ (odpowiednio 5,7 oraz 7,1 m, ryc. 11B). Odległości ciosowe skałkotwórczych piaskowców obu formacji dolnojurajskich są podobne do siebie. Dla piaskowców formacji skłobskiej wahają się pomiędzy $2,1 \mathrm{~m}$ a $6,2 \mathrm{~m}$, osiągając 
średnio 4,2 m, podczas gdy dla piaskowców formacji ostrowieckiej wahają się od 2,4 $\mathrm{m}$ do $5,4 \mathrm{~m}$, średnio wynosząc 4,5 m (ryc. 11B) (Urban, 2016).

Statystyka podsumowująca analizę miąższości warstw oraz odległości ciosowych (wykonana przy użyciu testu U Manna-Whitneya) wykazała podobieństwa rozkładów tych cech w wielu stanowiskach poszczególnych grup (formacji) piaskowców skałkotwórczych, a także pomiędzy grupami piaskowców mezozoicznych: warstw z Krynek, formacji skłobskiej i ostrowieckiej (Urban, 2016). Wyjątkiem pod tym względem są piaskowce kambryjskie, które wykazują w większości stanowisk skałkowych cienkopłytową oddzielność i bardzo gęsty cios, różniący je od innych skałkotwórczych piaskowców.

Istotne różnice pod względem grubości warstw oraz gęstości ciosu są widoczne pomiędzy mezozoicznymi piaskowcami skałkotwórczymi a niektórymi mezozoicznymi piaskowcami nietworzącymi skałek. Te ostatnie są często cienkopłytkowe lub występują w grubszych niż piaskowce skałkotwórcze - ławicach. Przykładem tych pierwszych są piaskowce formacji z Zagnańska, zaliczane do ogniwa z Tumlina, które - jako osady eoliczne - cechują się bardzo wielkoskalowym warstwowaniem przekątnym i w strefie odprężania oraz wietrzenia rozpadają się na warstwy o grubości zazwyczaj kilkunastu centymetrów (ryc. 11A). Podobnie piaskowce formacji ostrowieckiej w środkowej części północnego obrzeżenia oraz piaskowce formacji skłobskiej zachodniej części tego obrzeżenia, które nie tworzą form skałkowych, są często cienkopłytkowe i zawierają wkładki mułowcowo-ilaste (por. Guzik, 2017). Z kolei triasowe piaskowce wąchockie formacji z Baranowa wykazują większą od piaskowców skałkotwórczych grubość ławic, rzędu 2,5 m (Urban, 2016).

Podobne różnice pomiędzy mezozoicznymi piaskowcami skałkotwórczymi a pozostałymi są widoczne w przypadku gęstości ciosu. Nietworzące skałek piaskowce triasowe ogniwa z Tumlina, a także piaskowce jurajskie formacji drzewickiej odsłonięte w rejonie Szydłowca i Kunowa oraz formacji ostrowieckiej zachodniej części północnego obrzeżenia mają dwu- a nawet trzykrotnie rzadszy cios niż piaskowce skałkotwórcze (co jest bardzo dobrze widoczne na diagramie $\mathrm{z}$ danymi dla poszczególnych stanowisk ryc. 11C).

Mimo że gęstość ciosu była uznawana za istotny czynnik formowania się skałek już w pracach prezentujących pierwsze, klasyczne teorie dotyczące genezy tych form (Linton, 1955; Palmer, Radley, 1961), to nie udało się znaleźć wyników szczegółowych badań tej cechy w strefie klimatów umiarkowanych. Można jednak stwierdzić, że gęstość ciosu odróżnia skałki świętokrzyskie od wielu regionów piaskowcowych strefy klimatów umiarkowanych, zwłaszcza od obszaru czeskiej niecki kredowej, gdzie spękania ciosowe są generalnie znacznie rzadsze (Pulinowa, 1989; Alexandrowicz, 1990; Adamovič i in., 2006; Sandstone..., 2007; Wojewoda i in., 2011). Tam gdzie cios jest gęstszy skarpy piaskowcowe są niższe lub zanikają pod zwietrzeliną (Migoń, Tulaczyk, 2007; Remisz, 2008). Są jednak w Europie skałkotwórcze piaskowce o zasadniczo podobnej oddzielności poziomej, np. piaskowce niektórych formacji Karpat fliszowych (Alexandrowicz, 1978; Strzeboński, 2011), jak też niektóre piaskowce Wielkiej Brytanii (Robinson, Williams, 2005; Robinson, 2007).

\section{PRZESTRZENNE (TEKTONICZNE) UWARUNKOWANIA FORMOWANIA SIĘ SKAŁEK ŚWIĘTOKRZYSKICH}

Nachylenie piaskowców warunkuje pozycję skałek w stosunku do nadrzędnych elementów rzeźby: stoków, grzbietów czy wierzchowin, jak również kształt skałek (tab. 1).

Ponieważ zaś zaangażowanie tektoniczne skał w regionie świętokrzyskim jest najczęściej związane z ich wiekiem (ilością i natężeniem faz tektonicznych, którym podlegały), to $z$ reguły inna jest pozycja oraz kształt skałek zbudowanych z piaskowców paleozoicznych oraz mezozoicznych. Silnie zazwyczaj nachylone piaskowce kambryjskie i de-

Tab. 1. Położenie skałek w stosunku do nadrzędnych elementów rzeźby oraz kształt skałek w zależności od nachylenia warstw (wg Urbana, 2016, uaktualnione)

Table 1. The position of crags in relation to the superior morphological elements and the shape of crags against rock strata dip (after Urban, 2016, updated)

\begin{tabular}{|c|c|c|c|c|c|c|c|c|}
\hline \multirow{3}{*}{$\begin{array}{l}\text { Upad warstw } \\
\text { Strata dip } \\
{\left[{ }^{\circ}\right]}\end{array}$} & \multicolumn{4}{|c|}{$\begin{array}{c}\text { Pozycja skalek w stosunku do nadrzędnych } \\
\text { elementów topograficznych } \\
\text { Position of crags in relation to superior } \\
\text { morphological elements }\end{array}$} & \multicolumn{4}{|c|}{$\begin{array}{l}\text { Ksztalt skalek } \\
\text { Crag shape }\end{array}$} \\
\hline & $\begin{array}{l}\text { stokowe } \\
\text { (odsłonięte } \\
\text { czoła warstw) } \\
\text { hillslope } \\
\text { (joint } \\
\text { surfaces } \\
\text { outcropped) }\end{array}$ & $\begin{array}{l}\text { stokowe } \\
\text { (odłonięte } \\
\text { powierzchnie } \\
\text { warstw) } \\
\text { slope } \\
\text { (bedding } \\
\text { planes } \\
\text { outcropped) } \\
\end{array}$ & $\begin{array}{l}\text { przygrzbietowe, } \\
\text { przywierzchniowe } \\
\text { (kuesty) } \\
\text { near-ridge, } \\
\text { near-plateau } \\
\text { (cuesta-rims) }\end{array}$ & $\begin{array}{l}\text { grzbietowe } \\
\text { ridge }\end{array}$ & $\begin{array}{l}\text { progi, } \\
\text { ambony } \\
\text { cliffs, spurs }\end{array}$ & $\begin{array}{l}\text { baszty, } \\
\text { grzyby, stoły } \\
\text { skalne } \\
\text { pillars, } \\
\text { hoo-doo } \\
\text { rocks, } \\
\text { mushrooms }\end{array}$ & $\begin{array}{l}\text { platformy, } \\
\text { płyty } \\
\text { platforms, } \\
\text { slabs }\end{array}$ & $\begin{array}{l}\text { grzędy, } \\
\text { kopuły, mury } \\
\text { crests, } \\
\text { cupolas, } \\
\text { walls }\end{array}$ \\
\hline & \multicolumn{8}{|c|}{$\begin{array}{c}\text { liczba stanowisk skalkowych spelniająca dany warunek } \\
\text { number of sites fulfilling above-determined conditions }\end{array}$} \\
\hline $0-10$ & 22 & 0 & 19 & 4 & 35 & 25 & 5 & 1 \\
\hline $11-20$ & 6 & 0 & 3 & 1 & 10 & 3 & 1 & 1 \\
\hline $21-30$ & 1 & 1 & 1 & 1 & 2 & 1 & 1 & 2 \\
\hline $31-40$ & 1 & 1 & 4 & 5 & 4 & 2 & 2 & 6 \\
\hline $41-50$ & 1 & 0 & 0 & 5 & 1 & 0 & 0 & 5 \\
\hline $51-60$ & 1 & 1 & 0 & 0 & 1 & 0 & 0 & 2 \\
\hline $61-70$ & 0 & 1 & 0 & 2 & 1 & 0 & 0 & 3 \\
\hline $71-80$ & 1 & 0 & 0 & 0 & 0 & 1 & 0 & 0 \\
\hline $81-90$ & 0 & 0 & 0 & 0 & 0 & 0 & 0 & 0 \\
\hline
\end{tabular}




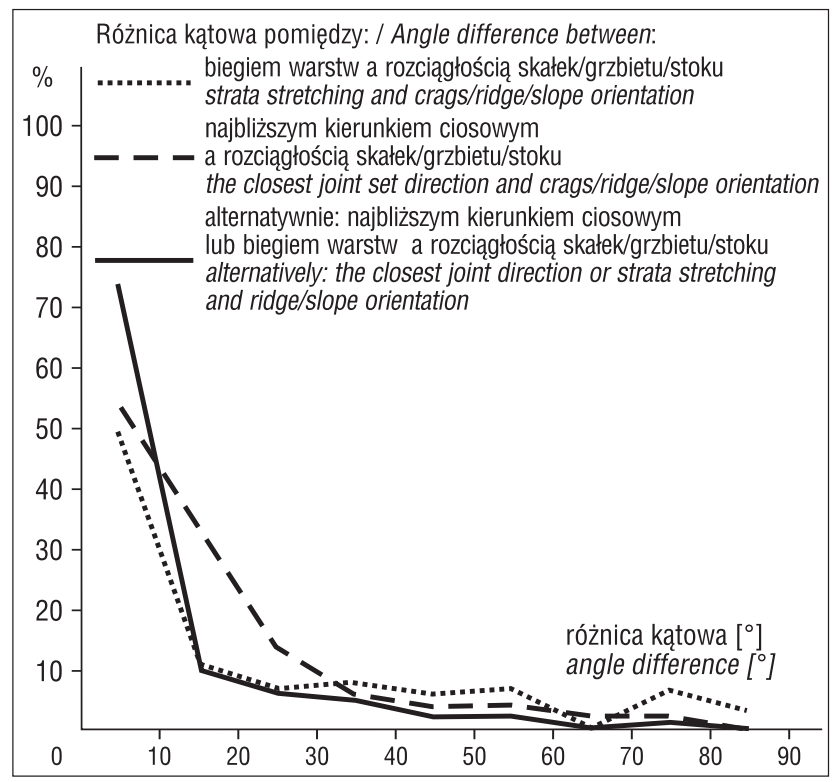

Ryc. 12. Różnica kątowa pomiędzy rozciągłością warstw i/lub kierunkiem jednego z zespołów ciosu a wydłużeniem grup skałkowych lub stoków (grzbietów), wyrażona procentowym udziałem interwałów kątowych o wielkości $10^{\circ} \mathrm{w}$ przedziale $0-90^{\circ}$ (wg Urbana, 2016)

Fig. 12. Angle differences between strata strike and/or joint orientation and the extension of crag groups or ridges (slopes) expressed as a percentage of the angle values of these differences in $10^{\circ}$ intervals from $0^{\circ}$ to $90^{\circ}$ (after Urban, 2016)

wońskie tworzą grzbietowe grzędy lub też pochylone stoły na stromych stokach. Grzędy tworzą również stosunkowo silnie nachylone triasowe piaskowce formacji z Zagnańska w zdeformowanej tektonicznie strefie na przedłużeniu uskoku świętokrzyskiego (ryc. 1, nr 6-8), podczas gdy skałki zbudowane z piaskowców tej samej formacji o niewielkim nachyleniu podobne są pod względem występowania na stoku i kształtu do skałek zbudowanych z innych piaskowców mezozoicznych. Te zaś tworzą najczęściej przywierzchowinowe progi i ambony in situ oraz stokowe bloki (stoły, kopuły lub ambony skalne) (tab. 1).

Pozycja skałek w obrębie nadrzędnych form rzeźby oraz ich wydłużenie wykazują związek z kierunkami tektonicznymi. W przypadku 50\% skałek, dla których udało się określić precyzyjnie rozciągłość warstw (czyli nachylonych pod kątem co najmniej $5^{\circ}$ ) różnica kątowa pomiędzy biegiem warstw a wydłużeniem skałek, grup skałkowych lub elementów w obrębie których te skałki występują jest mniejsza niż $5^{\circ}$. W nieco ponad połowie stanowisk $(55 \%)$ elementy te wydłużone są zgodnie $\mathrm{z}$ jednym $\mathrm{z}$ kierunków ciosowych. Biorąc pod uwagę alternatywnie bieg warstw oraz kierunki płaszczyzn ciosowych, zgodność pomiędzy tymi cechami i rozciagłością skałek (grup skałkowych) lub nadrzędnych elementów rzeźby występuje w przypadku $75 \%$ stanowisk, w których można te parametry pomierzyć (ryc. 12).

\section{PROCESY KSZTALTUJACE SKAŁKI ŚWIĘTOKRZYSKIE}

Powstanie i ukształtowanie skałek świętokrzyskich jest efektem działania zespołu procesów odsłaniających serie piaskowcowe i następnie kształtujących pionowe lub stromo nachylone ściany utworzone w piaskowcach. W regionie świętokrzyskim odpowiedzialne za odsłanianie i ewo- lucję form skałkowych są trzy główne procesy generowane czynnikiem grawitacyjnym: (i) deformacje dużych masywów skalnych w obrębie stoków, (ii) ruchy bloków piaskowcowych na powierzchni stoków, (iii) transformacje pokryw stokowych.

Deformacje dużych mas skalnych polegają na rozpadzie, rozsuwaniu się (lateral spreading) i przechylaniu (toppling) fragmentów serii piaskowcowych w obrębie stoków, w różnej skali. Zjawisko to, powszechnie obserwowane w wysokich górach (Agliardi i in., 2012), wydaje się wyjątkowe w regionie takim jak Góry Świętokrzyskie, gdzie gradient topograficzny jest bardzo niewielki i nie obserwuje się współcześnie głębokich osuwisk. Jest ono jednak dokumentowane w tym regionie badaniami geofizycznymi wykonanymi metodą ERT w dwu stanowiskach: Skaty w Krynkach (nr 75, ryc. 1), Skaty pod Adamowem (nr 67, ryc. 1 i 8), jak również bezpośrednimi pomiarami pozycji poszczególnych skałek w stanowiskach Rejów (nr 23) oraz Skatki Piekło pod Niekłaniem (nr 17). W tych dwu pierwszych stanowiskach takimi ruchami zostały objęte fragmenty pakietów piaskowcowych o wielkości kilkudziesięciu metrów, zaś skala przesunięć mogła sięgać kilkuset metrów, podczas gdy w przypadku dwu następnych obserwacje dowodzą skali przesunięć rzędu kilku, kilkunastu metrów (Urban i in., 2015). Podstawowymi warunkami ruchów grawitacyjnych była obecność w podłożu piaskowców skał podatnych na plastyczne deformacje: iłowców, mułowców, heterolitów, jak również istnienie czynników zewnętrznych generujących zmiany. Najbardziej prawdopodobnym mechanizmem generującym takie deformacje było uplastycznienie podłoża piaskowców w rezultacie wzrostu ciśnienia porowego wody, niszczącego struktury skały w czasie jej rozmrażania, tzw. cambering (Parks, 1991; Harris, 2006). Proces taki mógł występować wielokrotnie podczas oscylacji zasięgu wieloletniej zmarzliny podczas wahnięć klimatycznych na przełomie okresów glacjalnych oraz interglacjalnych. Morfologia stanowisk w Niekłaniu i Rejowie sugeruje, że w ich przypadku procesy te mogły zachodzić w późnym glacjale, zaś w Rejowie - nawet później, w holocenie. Inną przyczyną deformacji stoków w przypadku stanowisk w Adamowie i Krynkach mogło być rozmrażanie wieloletniej zmarzliny, powiązane $\mathrm{z}$ naciskiem lądolodu i głębokimi rozmyciami podłoża wzdłuż doliny rzeki Kamiennej podczas maksymalnego zasięgu lądolodu zlodowacenia odry. Duże deformacje mają więc charakter kopalny, jednak niewielkie ruchy masywów skalnych mogą zachodzić współcześnie (Urban i in., 2015, 2019; Urban, 2015b; Urban, Kasza, 2019).

Istotną rolę w powstawaniu ścian (progów) skalnych oraz w kształtowaniu grup skałkowych odegrały grawitacyjne przemieszczenia bloków na powierzchniach stoków. Przemieszczenia translacyjne $\mathrm{i} /$ lub rotacyjne, $w$ tym przechył, rotacja wsteczna lub boczna, rotacja wokół osi pionowej czy podnoszenie (dokumentowane pomiarami położenia powierzchni ławicowych i ciosowych - ryc. 4, 6, 7) następowały często na stokach o bardzo niewielkim nachyleniu, rzędu $5^{\circ}$ lub mniejszym. Ruch bloków na słabo nachylonych stokach jest związany $\mathrm{z}$ obecnością serii iłowcowo-mułowcowych lub marglistych w podłożu serii piaskowcowych. Pozycje bloków wskazują na dwa mechanizmy ich transportu (Urban, 2015a): (i) pasywny transport spowodowany plastycznymi deformacjami podłoża, np. podnoszenie bloków w wyniku wygniatania plastycznych osadów spod serii piaskowcowej i ich spiętrzania na przedpolu wychodni serii (stół skalny w stanowisku Adamów- 
-Północ, widoczny na przekroju i fotografii - ryc. 7B, C); (ii) powolne, indywidualne spełzywanie bloków po powierzchni o zmniejszonym współczynniku tarcia. Uplastycznienie i zmniejszenie oporów tarcia następowało głównie w wyniku opisywanego już wyżej procesu zwanego cambering, w późnym glacjale (co potwierdzają datowania OSL - Urban, 2015a), a także dopływu wód w okresach zwilgotnienia klimatu. Bloki występujące w świętokrzyskich grupach skałkowych nie powinny być jednak utożsamiane $\mathrm{z}$ tzw. blokami płużącymi (ploughing boulders, Ballantyne, 2001), których ruchy, związane z sezonowymi zmianami temperatury, następują w obrębie pokryw soliflukcyjnych. Podobnie do koncepcji sformułowanej przez Duszyńskiego i Migonia (2015) na podstawie obserwacji w Górach Stołowych, można sadzić, że większość bloków w skałkach świętokrzyskich nie podlegała gwałtownym ruchom, jednakże - inaczej niż w Górach Stołowych rola przesunięc zbliżonych do poziomych w przypadku skałek świętokrzyskich wydaje się ewidentna. Dokumentowana jest ona zróżnicowaną pozycją bloków, ich stopniem zwietrzenia podobnym do ścian skalnych in situ oraz uzasadniona podatnością podłoża na uplastycznienie w określonych warunkach (Urban, 2015a).

Podstawowe znaczenie dla odsłaniania skałek miało usuwanie luźnych osadów przykrywających serie piaskowcowe. Erozja wychodni (ścian) piaskowcowych - ewidentnie szybsza w warunkach klimatu peryglacjalnego niż współcześnie (Curry, Morris, 2004; Cílek, Žák, 2007) - musiała być bowiem wolniejsza niż usuwanie materiału zwietrzelinowego gromadzącego się w formie pokryw w ich sąsiedztwie. Pokrywy stokowe w otoczeniu skałek reprezentują piaski i diamiktony powstałe $\mathrm{z}$ materiału pochodzącego z otaczających piaskowców, w których występuje domieszka ziarn pochodzenia eolicznego. Znikomy udział lub brak materiału fluwioglacjalnego i glacjalnego sugeruje szybki transport i usuwanie osadu. Jak wskazują datowania OSL (Urban, 2015a), obecne pokrywy stokowe utworzyły się podczas pleniglacjalnego pessimum Vistulianu oraz $\mathrm{w}$ późnym glacjale. Najmłodsze daty OSL sugerują wczesnoholoceński wiek osadów, ale mogą być odmłodzone (odmłodzenie spowodowane różnym zawodnieniem osadów jest sugerowane np. przez odwrócenie dat w Piekle Dalejowskim - Urban, 2015a). Pokrywy te powstały w wyniku mechanicznego wietrzenia piaskowców oraz grawitacyjnego pełznięcia zwietrzeliny w dół stoku. Ze względu na uziarnienie (przewagę średnich ziarn frakcji piaszczystej, brak frakcji pylasto-ilastych) osady nie stanowiły jednak typowych pokryw soliflukcyjnych (frost susceptible soils Beskow, 1991; Motsuoka, 2001). Tym niemniej również tego typu osady ulegają procesom powolnego pełznięcia na stokach (Ballantyne, 1993; Goździk, French, 2004). Rola procesów eolicznych w formowaniu skałek świętokrzyskich, uznawana dawniej za podstawową (Lindner, 1972, 1977), jest trudna do oceny, chociaż obecność ziarn pochodzących z transportu eolicznego w pokrywach, wskazuje na aktywność tych procesów podczas górnego pleniglacjału i późnego glacjału (Urban, 2015a).

\section{DYSKUS.JA - WSPÓŁZALEŻNOŚĆ CECH I CZYNNIKÓW W PROCESIE FORMOWANIA SKALEK}

Analiza uwarunkowań formowania skałek w regionie świętokrzyskim wykazuje, że żadna z geologicznych cech piaskowców nie decyduje niezależnie o zdolności ich powstawania (Urban, 2016). Każdy z branych pod uwagę parametrów warunkuje morfogenezę skałek zbudowanych z piaskowców poszczególnych jednostek litologicznych w swoisty sposób, w korelacji z innymi cechami (por. np. Cílek i in., 2007; Young i in., 2009). Podstawową cechą petrograficzną piaskowców jest ich krzemionkowy skład, który jest odpowiedzialny za ich relatywnie wysoką odporność na wietrzenie chemiczne oraz wietrzenie solne (por. Stück i in., 2013). Co prawda dane literaturowe wskazuja, że skałki zbudowane z piaskowców o innym, niekrzemionkowym spoiwie występują na stokach o dużej wysokości i nachyleniu (stokach górskich, zboczach głębokich dolin np. Alexandrowicz, 1978, 1990; Colbach, 2005; Adamovič i in., 2006, 2015; Zhu i in., 2010), ale na obszarach o zdecydowanie wyższej dynamice procesów erozyjnych i grawitacyjnych niż w regionie świętokrzyskim.

Zawartość krzemionki w strukturze skały warunkuje jednocześnie pozostałe cechy fizyczne i mechaniczne piaskowców decydujące o ich odporności na działanie czynników niszczących. W przypadku skał paleozoicznych przesycenie krzemionką i praktyczny brak porowatości otwartej, które wyrażają się ich wysoką wytrzymałością na ściskanie i niską ścieralnością (ryc. 10), są istotnymi cechami decydującymi o odporności skałek. Natomiast w przypadku skałkotwórczych piaskowców mezozoicznych czynnikami decydującymi o ich odporności mechanicznej jest nierównoziarnistość (wynikająca z warunków sedymentacji) oraz silna kompakcja (ryc. 9), która decyduje o swoistej kohezji wewnętrznej skały (por. np. Bruthans i in., 2013, 2014; Stück i in., 2013; Young, Wray, 2015). Porowatość piaskowców nie musi przyczyniać się do znacznej efektywności wietrzenia mrozowego tych skał, jeśli jest ona na tyle wysoka i otwarta, że możliwy jest swobodny wzrost kryształków lodowych. Skałki świętokrzyskie nie są pod tym względem wyjątkiem, bowiem formy skałkowe zbudowane z piaskowców o niskich parametrach wytrzymałościowych notuje się w innych regionach strefy klimatów umiarkowanych i ciepłych (Robinson, Williams, 2005; Robinson, 2007; Thiry, 2005; Young i in., 2009; Young, Wray, 2015).

Następną cechą piaskowców, która w sposób istotny sprzyja powstawaniu form skałkowych, jest występowanie pakietów tych skał o miąższości kilku, kilkunastu metrów w profilu litostratygraficznym w otoczeniu utworów ilasto-mułowcowych lub heterolitowych. Taka pozycja piaskowców powoduje nie tylko odmienny charakter denudacji, szybszej w przypadku skał otoczenia piaskowców, co prowadzi do zestromienia ich wychodni (Olędzki, 1976), ale przede wszystkim przyczynia się do grawitacyjnych deformacji masywów piaskowcowych, powodujących odsłanianie się ścian skalnych (wzdłuż powierzchni ciosowych), oraz kształtowanie się grup skałkowych. Rola tych procesów zależy od położenia przestrzennego (nachylenia) pakietów piaskowcowych oraz ich spękania ciosowego (gęstości spękań i ich oraz orientacji przestrzennej) i uławicenia (ryc. 11) (Urban 2015a, 2016). W przypadku poziomo leżących lub słabo pochylonych piaskowców mezozoicznych, które tworzą przywierzchowinowe ściany, progi i ambony skalne oraz bloki, odpowiednie odległości spękań warunkowały grawitacyjną stabilność części masywu skalnego, ale jednocześnie umożliwiały w warunkach peryglacjalnych dylatacyjno-grawitacyjną fragmentację brzeżnych części masywu - proces, który miał zasadnicze znaczenie dla tworzenia się grup skałkowych. Z kolei w przypadku kambryjskich piaskowców kwarcytowych 
Tab. 2. Cechy typowe dla skałkotwórczych piaskowców w Górach Świętokrzyskich (wg Urbana, 2016)

Table 2. Typical features of crag-forming sandstones in the Świętokrzyskie Mts. (after Urban, 2016)

\begin{tabular}{|c|c|c|c|c|c|c|}
\hline \multirow[b]{2}{*}{$\begin{array}{l}\text { Cechy i parametry } \\
\text { Features and } \\
\text { parameters }\end{array}$} & \multirow{2}{*}{\begin{tabular}{|c|} 
Kambr / Cambrian \\
fm. z Wiśniówki \\
Wiśniówka Fm
\end{tabular}} & \multirow{2}{*}{\begin{tabular}{|c|} 
Dewon / Devonian \\
fm. barczańska, \\
fm. zagórzańska \\
Barcza Fm, \\
Zagórze Fm \\
\end{tabular}} & \multicolumn{2}{|c|}{ Trias / Triassic } & \multicolumn{2}{|c|}{ Jura / Jurassic } \\
\hline & & & $\begin{array}{l}\text { fm. z Zagnańska } \\
\text { Zagnańsk Fm }\end{array}$ & $\begin{array}{l}\text { warstwy z Krynek } \\
\text { Krynki Beds }\end{array}$ & $\begin{array}{l}\text { formacja skłobska } \\
\quad \text { Skłoby Fm }\end{array}$ & $\begin{array}{c}\text { formacja } \\
\text { ostrowiecka } \\
\text { Ostrowiec Fm }\end{array}$ \\
\hline \multirow{2}{*}{$\begin{array}{l}\text { System depozycyjny } \\
\text { (warunkujący } \\
\text { struktury) } \\
\text { Depositional system } \\
\text { (conditioning } \\
\text { structural pattern) }\end{array}$} & \multicolumn{6}{|c|}{ wysokoenergetyczne środowiska sedymentacji / high-energy depositional environments } \\
\hline & $\begin{array}{l}\text { głebooko- lub } \\
\text { płytkomorskie } \\
\text { marine: shallow } \\
\text { or deep }\end{array}$ & $\begin{array}{c}\text { płytkomorskie lub } \\
\text { rzeczne } \\
\text { shallow-marine } \\
\text { or fluvial }\end{array}$ & $\begin{array}{l}\text { rzeczne (rzeki } \\
\text { roztokowe) } \\
\text { fluvial (braided } \\
\text { river) }\end{array}$ & $\begin{array}{c}\text { płytkomorskie lub } \\
\text { rzeczne } \\
\text { shallow-marine } \\
\text { or fluvial }\end{array}$ & \multicolumn{2}{|c|}{$\begin{array}{l}\text { płytkomorskie, plażowe } \\
\text { shallow-marine (upper shoreface) }\end{array}$} \\
\hline $\begin{array}{l}\text { Skład mineralny } \\
\text { Mineral composition }\end{array}$ & \multicolumn{6}{|c|}{ arenity kwarcowe lub sublityczne, spoiwo krzemionkowe / quartzose or sublithic arenites,siliceous cement } \\
\hline \multirow{2}{*}{$\begin{array}{l}\text { Struktura } \\
\text { Fabric }\end{array}$} & \multirow{2}{*}{$\begin{array}{c}\text { bardzo drobno } \\
\text { i drobnoziarniste } \\
\text { very fine } \\
\text { and fine-grained }\end{array}$} & \multirow{2}{*}{$\begin{array}{l}\text { drobnoziarniste, } \\
\text { lokalnie grubsze } \\
\text { fine-grained, } \\
\text { occas. coarser }\end{array}$} & \multirow{2}{*}{$\begin{array}{l}\text { nierównoziarn., } \\
\text { zlepieńcowate } \\
\text { poorly sorted, } \\
\text { fine pebbles } \\
\end{array}$} & $\begin{array}{c}\text { nierównoziarnist } \\
\text { poorly sorted }\end{array}$ & \multicolumn{2}{|c|}{$\begin{array}{l}\text { drobno-średnioziarniste } \\
\text { fine-medium grained }\end{array}$} \\
\hline & & & & \multicolumn{3}{|c|}{ silna kompakcja / high compaction } \\
\hline $\begin{array}{l}\text { Przestrzeń } \\
\text { międzyziarn. } \\
\text { Intergranular space } \\
{[\%]}\end{array}$ & 0 & $0-2$ & $5-10$ & $5-15$ & \multicolumn{2}{|c|}{$10-15$} \\
\hline $\begin{array}{l}\text { Nasiakliwość } \\
\text { Water absorption } \\
{[\%]}\end{array}$ & ca 0,5 & $0-2$ & $3-5$ & $4-6$ & \multicolumn{2}{|c|}{$4-8$} \\
\hline $\begin{array}{l}\text { Wytrzymałość } \\
\text { na ściskanie } \\
\text { Compr. strenght } \\
\text { [Mpa] }\end{array}$ & ca 200 & ca 150 & $30-60$ & $30-80$ & $20-80$ & $30-50$ \\
\hline $\begin{array}{l}\text { Miąższość ławic } \\
\text { Bedding thickness } \\
{[\mathrm{m}]}\end{array}$ & $0,7(0,3-1,0)$ & $1,2(0,7-2,0)$ & $1,3(0,9-2,1)$ & $0,9(0,2-2,1)$ & \multicolumn{2}{|c|}{$1,1(0,9-1,6)$} \\
\hline $\begin{array}{l}\text { Odległości ciosowe } \\
\text { Joint spacing } \\
{[\mathrm{m}]}\end{array}$ & ca 1 & ca 2 & $3(2-6)$ & $6(3-11)$ & \multicolumn{2}{|c|}{$4(2-6)$} \\
\hline $\begin{array}{l}\text { Upad warstw } \\
\text { Strata dip } \\
{\left[{ }^{\circ}\right]}\end{array}$ & $10-50$ & $10-40$ & $5-20$ & \multicolumn{3}{|c|}{$0-5$} \\
\hline
\end{tabular}

i części triasowych piaskowców formacji z Zagnańska, bardziej strome nachylenie warstw oraz ich gęste spękanie były czynnikami decydującymi o relatywnej stabilności grawitacyjnej masywów (mimo gęstego spękania) oraz powstawaniu skałek mających kształt grzęd i kopuł skalnych wieńczących grzbiety. Podobne nachylenie warstw, lecz rzadziej występujące spękania w obrębie piaskowców wieku dewońskiego, sprzyjały z kolei powstawaniu form przygrzbietowych i stokowych o charakterze stołów i progów (tab. 1).

Odległości ciosowe i grubość ławic (ryc. 11) mają szczególne znaczenie dla mniej odpornych na wietrzenie mezozoicznych piaskowców skałkotwórczych, bowiem procesy niszczące (wierzenie, erozja) rozwijają się od powierzchni spękań i uławicenia w głąb skały i - w konsekwencji znaczne odległości ciosowe wydłużają czas zniszczenia masywów skalnych. Dlatego dla piaskowców skałkotwórczych można określić optymalne (dla rozwoju skałek) wartości grubości ławic oraz odległości spękań, które są warunkowane przez dwa czynniki: (i) czas zniszczenia bloku skalnego postępującego od jego granic, czyli powierzchni ławicowych i ciosowych, oraz (ii) możliwości grawitacyjnego rozpadu masywu (odsuwania się bloków odciętych spękaniami od wychodni serii piaskowcowej). Zbyt gęsty cios i uławicenie powodują w przypadku tych piaskowców szybki i całkowity rozpad fragmentów skalnych, natomiast duże, odcięte rzadkim ciosem fragmenty skalne nie mają możliwości odsuwania się od wychodni serii, co uniemożliwia kształtowanie się ścian skalnych. Z kolei istotnym czynnikiem warunkującym formowanie się skałek zbudowanych $\mathrm{z}$ pia- skowców paleozoicznych o gęstych spękaniach ciosowych jest wyraźne nachylenie ławic w kierunku przeciwnym do ekspozycji ścian skalnych, utrudniające grawitacyjne odpadanie niewielkich i niestabilnych fragmentów skalnych odciętych tymi powierzchniami (Urban, 2016).

Można więc sformułować tezę, że odpowiednie relacje pomiędzy odpornością skał na denudację, gęstością ciosu i uławicenia oraz tektoniką (orientacją ciosu i uławicenia) decydowały o rozwoju skałek, ich kształcie oraz formie grup skałkowych (tab. 2).

\section{PODSUMOWANIE}

Analiza uwarunkowań geologicznych powstawania oraz istnienia skałek piaskowcowych w regionie świętokrzyskim wykazuje, że zdolności do tworzenia się tych form są warunkowane przez cały zespół cech litostratygraficznych, litologicznych i strukturalnych piaskowców. Podstawowa cecha petrograficzna piaskowców skałkotwórczych - krzemionkowy skład - jest odpowiedzialna za ich relatywnie wysoką odporność na wietrzenie, w tym tzw. wietrzenie solne i mrozowe, przy czym stosunkowo niskie tempo tego procesu jest uzależnione od różnych cech piaskowców. W przypadku nasyconych krzemionką piaskowców paleozoicznych tą cechą jest ich wysoka mechaniczna wytrzymałość, natomiast w przypadku piaskowców mezozoicznych o ubogim spoiwie - silna kompakcja skał o nierównoziarnistej strukturze, jednolitym, krzemionkowym składzie mineralnym i porowatości otwartej uniemożliwiającej krystalizacyjne rozsadzanie skały. 
Formy skałkowe w regionie świętokrzyskim tworzą się na wychodniach pakietów piaskowcowych o miąższości rzędu kilku, kilkunastu metrów, podścielonych utworami ilasto-mułowcowymi lub heterolitowymi. Uplastycznienie podłoża piaskowców, zachodzące przede wszystkim w warunkach degradacji wieloletniej zmarzliny w późnym plejstocenie, ale także wcześniej w okresach glacjalnych, decydowało o grawitacyjnych deformacjach fragmentów pakietów piaskowcowych w różnej skali: od całych stoków, po poszczególne bloki skalne. Procesy te, mające istotne znaczenie dla odsłaniania ścian oraz formowania grup skałkowych, były warunkowane pozycją przestrzenną (nachyleniem i rozciagłością) pakietów piaskowcowych oraz orientacją i gęstością spękań ciosowych. Litologia skał (krzemionkowy skład i różny udział krzemionki), gęstość spękań oraz grubość ławic decydowały jednocześnie o tempie denudacji poszczególnych elementów pakietów piaskowcowych. W związku z tym wielkości tych parametrów są różne, charakterystyczne dla poszczególnych typów piaskowców skałkotwórczych.

Badania genezy i rzeźby skałek piaskowcowych w regionie świętokrzyskim były celem projektu badawczego Litologiczne, tektoniczne i egzogeniczne uwarunkowania rozwoju oraz ewolucji świętokrzys- kich skałek piaskowcowych (2 P04E 049 29), finansowanego przez Ministerstwo Nauki i Szkolnictwa Wyższego i realizowanego w Instytucie Ochrony Przyrody PAN w latach 2006-2010. Autor dziękuje Recenzentom za cierpliwość, bardzo staranne przejrzenie manuskryptu i uwagi, które zostały uwzględnione przy ostatecznym opracowaniu materiałów do publikacji.

\section{LITERATURA}

ADAMOVIČ J., MIKULÁŠ R., CÍLEK V. 2006 - Sandstone districts of the Bohemian Paradise: emergence of a romantic landscape. Geolines, 21: $1-100$.

ADAMOVIČ J., MIKULAŠ R., NAVRATIL T. 2015 - Spherical and ellipsoidal cavities in European sandstones: a product of sinking carbonate dissolution front. Z. Geomorph., 59, Suppl. 1: 123-149.

AGLIARDI F., CROSTA G.B., FRATTINI P. 2012 - Slow rock-slope deformation. [W:] Clogue J.J., Stead D. (red.), Landslides. Types, mechanics and modelling. Cambridge Univ. Press, New York: 207-221.

ALEXANDROWICZ Z. 1978 - Skałki piaskowcowe zachodnich Karpat fliszowych. Pr. Geol. PAN, Oddz. w Krakowie, 113: 1-87.

ALEXANDROWICZ Z. 1990 - The optimum system of tors protection in Poland. Ochrona Przyr., 47: 277-308.

ALEXANDROWICZ Z., DRZAŁ M., KOZŁOWSKI S. 1975 - Katalog rezerwatów i pomników przyrody nieożywionej w Polsce. Stud. Nat., ser. B, 26: 1-298.

ALEXANDROWICZ Z., URBAN J. 2005 - Sandstone regions of Poland - geomorphological types, scientific importance and problems of protection. Ferrantia, 44: 131-136.

BALLANTYNE C.K. 1993 - An Tellach. [W:] Gordon J.E., Sutherland D.G. (red.), Quaternary of Scotland. Chapman \& Hall, London: 110-115.

BALLANTYNE C.K. 2001 - Measurement and theory of ploughing boulder movement. Permafrost and Periglacial Processes, 12: 267-288. BARCZUK A. 1979 - Studium petrograficzne utworów pstrego piaskowca w północno-wschodniej części obrzeżenia Gór Świętokrzyskich. Arch. Miner., 35: 87-155.

BESKOW G. 1991 - Soil freezing and frost heaving with special applications to roads and railroads. [W:] Block P.B., Hardenberg M.J. (red.) Historical perspectives in frost heave research. The early works of S. Taber and G. Beskow. US Army Corps of Engineers. Cold Regions Research. Eng. Lab. Spec. Rep., 91-93: 37-157.

BRUTHANS J., SOUKUP J., SCHWEIGSTILLOVÁ J., VACULIKOVÁ J., SMUTEK D., MAYO A.L., FELTEISEK L. 2013 - Origin of "rock cities", pillars and cleft conduits in kaolinite-bounded sandstone: New insight from study in sandstone quarry where land form recently evolve. [W:] Filippi M., Bosák P. (red.), Proc. $16^{\text {th }}$ Intern. Congress of Speleology, 21-28.07.2013, Brno. Czech Speleol. Soc., 3: 247-252. BRUTHANS J., SOUKUP J., VACULIKOVÁ J., SCHWEIGSTILLOVÁ J., MAYO A.L., MASIN D., KLETETSCHKA G., RIHOSEK J. 2014 -
Sandstone landforms shaped by negative feedback between stress and erosion. Nat. Geosci., 7: 597-601

CHLEBOWSKI R., LINDNER L. 1991 - Žródła materiału i warunki akumulacji lessów młodszych Wyżyny Małopolskiej. Biul. Geol. Wydz. Geol. UW, 32: 15-50.

CÍLEK V., WILLIAMS R., OSBORNE A., MIGOŃ P., MIKULAŠ R. 2007 - The origin and development of sandstone landscapes. [W:] Härtel H., Cílek V., Herben T., Jackson A., Williams R. (red.), Sandstone landscapes. Academia, Praha: 34-43.

CÍLEK V., ŽAK K. 2007 - Late Glacial and Holocene sedimentation under sandstone rock shelters of Northern Bohemia. [W:] Härtel H., Cílek V., Herben T., Jackson A., Williams R. (red.), Sandstone Landscapes. Academia, Praha: 133-138.

COLBACH R. 2005 - Overview of the geology of the Luxembourg Sandstone(s). Ferrantia, 44: 155-160.

CURRY A.M., MORRIS C.J. 2004 - Lateglacial and Holocene talus slope development and rock Wall retreat on Mynydd Du, UK. Geomorph., 58: 85-106.

DUSZYŃSKI F., MIGOŃ P. 2015 - Boulder aprons indicate long-term gradual and non-catastrophic evolution of cliffed escarpments, Stołowe Mts., Poland. Geomorph., 250: 63-77.

DUSZYŃSKI F., MIGOŃ P., STRZELECKI M.C. 2019 - Escarpment retreat in sedimentary tablelands and cuesta landscapes - landforms, mechanisms and patterns. Earth Sci. Rev., 196 (w druku).

GĄGOL J., KULETA M., ZBROJA S. 2005 - Odmiany litologiczno-surowcowe dekoracyjnych piaskowców budowlanych dolnego triasu $\mathrm{w}$ Górach Świętokrzyskich (manuskrypt). Nar. Arch. Geol. Państw. Inst. Geol., Oddz. Świętokrzyski, Kielce.

GOŽDZIK L., FRENCH H.M. 2004 - Apparent upfreezing of stones in Late Pleistocene coversand, Bełchatów vicinity, Central Poland. Permafrost Periglac. Proc., 15: 359-366.

GUBAŁA J., KASZA A., URBAN J. 1996 - G-4.1 Jaskinia Ponurego. [W:] Urban J. (red.), Jaskinie regionu świętokrzyskiego. Pol. Tow. Przyjaciół Nauk o Ziemi, Warszawa: 183-186.

GUZIK K. 2017 - Możliwości wykorzystania piaskowców jurajskich północno-zachodniego obrzeżenia gór świętokrzyskich jako kamieni architektonicznych w zależności od ich litologii. IGSMiE PAN. Studia, rozprawy, monografie, 205: 1-140.

HALL K., THORN C.E., SUMNER P. 2012 - On the persistence of weathering. Geomorph., 149-150: 1-10.

HARRIS C. 2006 - Cambering and valley bulging. [W:] Goudie A.S. (red.), Encyclopedia of Geomorphology. Taylor \& Francis Lib., London: 115-116.

HOUSKNECHT D.W. 1987 - Assessing the relative importance of compaction process and cementation to reduction of porosity in sandstones. The Amer. Assoc. Petrol. Geol. Bull., 71 (6): 633-642.

HOUSKNECHT D.W. 1989 - Assessing the relative importance of compaction process and cementation to reduction of porosity in sandstones: reply. The Amer. Assoc. Petrol. Geol. Bull., 73 (10): 1277-1279.

JAWOROWSKI K., SIKORSKA M. 2006 - Łysogóry Unit (Central Poland) versus East European Craton - application of sedimentological data from Cambrian siliciclastic association. Geol. Q., 50 (1): 77-88.

KOBYLEC K. 2008 - Dolnojurajskie piaskowce z okolic Przysuchy-Opoczna, ich wykształcenie i możliwości wykorzystania. Gosp. Sur. Miner., 24 (1-2): 59-72.

KOWALCZEWSKI Z. 2000 - Wybrane problemy geologii Pasma Głównego Gór Świętokrzyskich w świetle badań geofizycznych. Posiedz. Nauk. Państw. Inst. Geol., 56: 138-141.

KOWALCZEWSKI Z., KOWALSKI B., JANIEC J. 1989 - Wpływ budowy geologicznej na rzeźbę Pasma Klonowskiego w Górach Świętokrzyskich. Biul. Państw. Inst. Geol., 362: 65-95.

KOZLOWSKA A., KUBERSKA M. 2014 - Diageneza a porowatość piaskowców jury dolnej na Niżu polskim. Biul. Państw. Inst. Geol., 458: 39-60.

KOZYDRA Z. 1968 - Złoża dolnojurajskich iłów ogniotrwałych na tle budowy geologicznej północnego obrzeżenia Gór Świętokrzyskich. Biul. Inst. Geol., 216: 1-94.

KULETA M. 1976 - Petrografia pstrego piaskowca w północnym i zachodnim obrzeżeniu Gór Świętokrzyskich (manuskrypt). Nar. Arch. Geol. Państw. Inst. Geol., Oddz. Świętokrzyski, Kielce.

KULETA M. 1981 - Petrografia osadów dewońskich w obszarze północnym Gór Świętokrzyskich. Kwart. Geol., 24 (4): 827-828.

KULETA M. 1985 - Kompleksowe badania petrograficzno-sedymentologiczne osadów piaskowca pstrego w NW obrzeżeniu Gór Świętokrzyskich i niecce miechowskiej (manuskrypt). Nar. Arch. Geol. Państw. Inst. Geol., Oddz. Świętokrzyski, Kielce.

KULETA M. 2004 - Petrografia i rozwój sedymentacji osadów retu w rejonie Mniów-Suchedniów w Górach Świętokrzyskich (manuskrypt). Nar. Arch. Geol. Państw. Inst. Geol., Oddz. Świętokrzyski, Kielce. 
KULETA M., NAWROCKI J. 2000 - Litostratygrafia i magnetostratygrafia pstrego piaskowca w północnym obrzeżeniu Gór Świętokrzyskich (manuskrypt). Nar. Arch. Geol. Państw. Inst. Geol., Oddz. Świętokrzyski, Kielce.

KULETA M., ZBROJA S. 2006 - Wczesny etap rozwoju pokrywy permsko-mezozoicznej w Górach Świętokrzyskich. [W:] Skompski S., Żylińska A. (red.), Procesy i zdarzenia w historii geologicznej Gór Świętokrzyskich, Mat. 77 Zjazdu Nauk. Pol. Tow. Geol., Ameliówka k. Kielc, 28-30.06.2006 r. Warszawa: 104-125.

KUŽNIAR C. 1923 - Rudy żelazne w okolicach Niekłania. Sprawozd. Państw. Inst. Geol., 5: 6-7.

LINDNER L. 1972 - Geneza i wiek skałek piaskowcowych góry Piekło koło Niekłania. Acta Geol. Pol., 22 (1): 168-180.

LINDNER L. 1977 - Geneza i wiek skałek piaskowcowych góry Piekło oraz ich stosunek do pokrywy lessowej regionu świętokrzyskiego. [W: Lindner L., Michalska Z. (red.), Przew. Symp. Terenowego „Czwartorzęd zachodniej części regionu świętokrzyskiego”. Wyd. Geol., Warszawa: 60-65.

LINTON D.L. 1955 - The problem of tors. Geogr. J., 121: 470-487.

ŁOBANOWSKI H. 1990 - Lower Devonian terrains of clastic deposition in Poland and their affinnities to other European Devonian paleogeographic-facial provinces. Neues Jahrbuch Geol-Paläont., 7: 404-420.

MALEC J. 2004 - Środowisko sedymentacji osadów kambru w zachodniej części Gór Świętokrzyskich. Posiedz. Nauk. Państw. Inst. Geol. 61 (13): 53-55.

MASSALSKI E. 1936 - Skałka pod Szewna. Ziemia, 2-3: 85-86.

MASSALSKI E., KAZNOWSKI K. 1928 - Piaskowcowe skałki góry Piekło koło Niekłania. Ochr. Przyr., 8: 29-33.

MATSUOKA N. 2001 - Solifluction rates, processes and landforms: a global review. Earth Sci. Rev., 55: 107-134.

MIGOŃ P., DUSZYŃSKI F., GOUDIE A. 2017 - Rock cities and ruiniform relief: forms - processes - terminology. Earth Sci. Rev., 171: 78-104.

MIGOŃ P., TULACZYK S. 2007 - Relief-structure relationships in the Sandstone terrain of the north part of the Intrasudetic Trough, Sudetes (SW Poland). [W:] Härtel H., Cílek V., Herben T., Jackson A., Williams R. (red.), Sandstone landscapes. Academia, Praha: 51-55.

OLĘDZKI J. 1976 - Wpływ zróżnicowania budowy geologicznej na rzeźbę w Górach Świętokrzyskich. Prace i Studia Inst. Geogr. UW, 17., Geogr. Fiz., 6: 1-66.

PALMER J., RADLEY J. 1961 - Gritstone tors of the English Pennines. Z. Geomorph., 5: 37-52.

PARKS C.D. 1991 - A review of the mechanism of cambering and valley bulging. [W:] Forster A., Culshlaw M.G., Cripps J.C, Little J.A., Moon C.F. (red.), Eng. Geol. Spec. Publ. 7, Geol. Soc., London: 373-380.

PESZAT C. 1973 - Własności techniczne piaskowców Gór Świętokrzyskich. Zesz. Nauk. AGH, 378, Geologia, 18: 1-59.

PIEŃKOWSKI G. 2004 - The epicontinental Lower Jurassic of Poland. Special Papers, Pol. Geol. Inst., 12: 1-154.

PULINOWA M. 1989 - Rzeźba Gór Stołowych. Pr. UŚl., 1008: 1-215. REMISZ J. 2008 - Strukturalne uwarunkowania rozwoju progów denudacyjnych Gór Stołowych. Landform Analysis 9: 41-44.

RICHLING W. 1938 - Brama Piekło pod Suchedniowem. Wiad. Muz. Ziemi, 1: 37-38.

ROBINSON D.A. 2007 - Geomorphology of the inland sandstone cliffs of Southeast England. [W:] Härtel H., Cílek V., Herben T., Jackson A., Williams R. (red.), Sandstone Landscapes. Academia, Praha: 44-51.

ROBINSON D.A., WILLIAMS R.B.G. 1981 - Sandstone cliffs on the High Weald Landscape. Geograph. Mag., 55: 587-592.

ROBINSON D.A., WILLIAMS R.B.G. 2005 - Comparative morphology and weathering characteristic of sandstone outcrops in England, UK. Ferrantia, 44: 41-46

RUBINOWSKI Z. 1971 - Rudy metali nieżelaznych w Górach Świętokrzyskich i ich pozycja metalogeniczna. Biul. Inst. Geol., 241: 1-166. RUBINOWSKI Z., WRÓBLEWSKI T., GĄGOL J. red. 1986 - Atlas geologiczno-surowcowy Gór Świętokrzyskich 1:50 000. Wyd. Geol., Warszawa.

SANDSTONE... 2007 - Sandstone landscapes across Europe. [W:] Härtel H., Cílek V., Herben T., Jackson A., Williams R. (red.), Sandstone landscapes. Academia, Praha: 319-403.

SENKOWICZOWA H. 1970 - Trias. [W:] Stratygrafia mezozoiku obrzeżenia Gór Świẹtokrzyskich. Pr. Inst. Geol., 56: 7-48.

SIKORSKA M. 2000 - Historia sylifikacji w piaskowcach kambru z rejonu Wiśniówki w Górach Świętokrzyskich. Prz. Geol., 48: 251-258. STRZEBOŃSKI P. 2011 - The Mushroom Stone a geotouristic attraction of the Wiśnicz Foothill. [W:] Słomka T. (red.), Geotourism a variety of aspects. AGH, Kraków: 235-242.
STÜCK H., KOCH R., SIEGESMUND S. 2013 - Petrographical and petrophysical properties of sandstones: statistical analysis as an approach to predict material behaviour and construction suitability. Environ. Earth Sci., 69: 1299-1332.

TEOFILAK-MALISZEWSKA A. 1968 - Petrografia osadów liasu w północnym obrzeżeniu Gór Świętokrzyskich. Biul. Inst. Geol., 216: 107-192.

THIRY M. 2005 - Weathering morphologies of the Fontainebleau Sandstones and related silica mobility. Ferrantia, 44: 47-51.

TRELA W. 1998 - Środowisko sedymentacji piaskowców ,warstw z Krynek" w rejonie Nietuliska (NE obrzeżenie Gór Świętokrzyskich). Prz. Geol., 46 (1): 67-70.

TRICART J., CAILLEUX A. 1972 - Introduction to climatic geomorphology. Longmans, London.

TURKINGTON A.V., PARADISE T.R. 2005 - Sandstone weathering: a century of research and innovation. Geomorph., 67: 229-253.

URBAN J. 1986 - Mezozoiczne skałki piaskowcowe w północnej części województwa kieleckiego. Kwart. Geol., 30 (2): 421-422.

URBAN J. 1996 - Jaskinie pseudokrasowe w piaskowcach liasowych Piekła pod Niekłaniem. Kras i Speleologia, 8: 113-123.

URBAN J. 2014 - Cechy rzeźby strukturalnej Gór Świętokrzyskich i południowo-wschodniej części Niecki Nidziańskiej. Prz. Geol., 62 (1): 44-50.

URBAN J. 2015a - The role of gravitational processes in shaping sandstone rock landforms in low mountains: Świętokrzyskie (Holy Cross) Mountains, central Poland. Z. Geomorph., 59, Suppl. 1: 35-79.

URBAN J. 2015b - Skałki piaskowcowe w Rejowie oczami geologa. Piękne, rzadkie, chronione, cz. V. Skarżyskie Zesz. LOP, 14: 42-54.

URBAN J. 2016 - The geological constraints of the development of sandstone landforms in Central Europe, a case study of the Świętokrzyskie (Holy Cross) Mountains, Poland. Geomorph., 274: 31-49.

URBAN J. 2017 - Piekło Dalejowskie oczami geologa. Piękne, rzadkie, chronione, cz. VI. Skarżyskie Zesz. LOP, 15: 73-88.

URBAN J. 2019a - Stanowisko 2.3. Ruda. [W:] Urban J. (red.), VII Warsztaty Geomorfologii Strukturalnej „Rzeźba strukturalna Gór Świętokrzyskich i Ponidzia - stan badań i perspektywy badawcze”. Streszczenia referatów i posterów, przewodnik sesji terenowych. UJK, Kielce: 90-93.

URBAN J. 2019b - Skałki Pleśniówki jako inspiracja do rozważań o metodologii nauki. Piękne, rzadkie, chronione, cz. VIII. Skarżyskie Zesz. LOP, 17: 42-55.

URBAN J., FIJAŁKOWSKA-MADER A. 2018 - Brama Piekło oczami (nie tylko) geologów. Piękne, rzadkie i chronione, cz. VII. Skarżyskie Zesz. LOP, 16: 98-105.

URBAN J., GÓRNIK M. 2017 - Some aspects of lithological and exogenic control of sandstone morphology, the Świętokrzyskie (Holy Cross) Mts. case study, Poland. Geomorph., 295: 773-789.

URBAN J., JANKOWSKI M., KASZA A. 2019 - Stanowisko 2.5. Skałki Piekło pod Niekłaniem. [W:] Urban J. (red.), VII Warsztaty Geomorfologii Strukturalnej „Rzeźba strukturalna Gór Świętokrzyskich i Ponidzia stan badań i perspektywy badawcze". Streszczenia referatów i posterów, przewodnik sesji terenowych. UJK, Kielce: 99-106.

URBAN J., KASZA A. 2019 - Stanowisko 2.4. Skałki pod Adamowem. [W:] Urban J. (red.), VII Warsztaty Geomorfologii Strukturalnej „Rzeźba strukturalna Gór Świętokrzyskich i Ponidzia - stan badań i perspektywy badawcze". Streszczenia referatów i posterów, przewodnik sesji terenowych. UJK, Kielce: 94-98.

URBAN J., PÁNEK T., HRADECKÝ J., TÁBOŘÍK P. 2015 - Deep structures of slopes connected with sandstone crags in the upland area of the Swiętokrzyskie (Holy Cross) Mountains, Central Poland. Geomorph., 246: $519-530$

WOJEWODA J., BIAŁEK D., BUCHA M., GLUSZYŃSKI A., GOTOWAŁA R., KRAWCZEWSKI J., SCHUTTY B. 2011 - Geologia Parku Narodowego Gór Stołowych - wybrane zagadnienia. [W:] Chodak T., Kabała C., Kaszubkiewicz J., Migoń P., Wojewoda J. (red.), Geoekologiczne warunki środowiska przyrodniczego Parku Narodowego Gór Stołowych. WIND, Wrocław: 53-96.

YOUNG R.W., WRAY R.A.L. 2015 - Rock control in sandstone geomorphology: a tribute to Eiju Yatsu with some Australian examples. Z. Geomorph., 59, Suppl. 1: 3-17.

YOUNG R.W., WRAY R.A.L., YOUNG A.R. 2009 - Sandstone landforms. Cambridge Univ. Press, Cambridge.

ZHU C., PENG H., QUYANG J., HU Z., LI L. 2010 - Rock resistance and the development of horizontal grooves on Danxia slopes. Geomorph., 123: 84-96. 
Strukturalne, litologiczne oraz tektoniczne uwarunkowania rozwoju i ewolucji świętokrzyskich skalek piaskowcowych - patrz str. 112

Structural, lithological and tectonic constraints of development and evolution of sandstone tors in the Świętokrzyskie (Holy Cross) Mountains - see p. 112

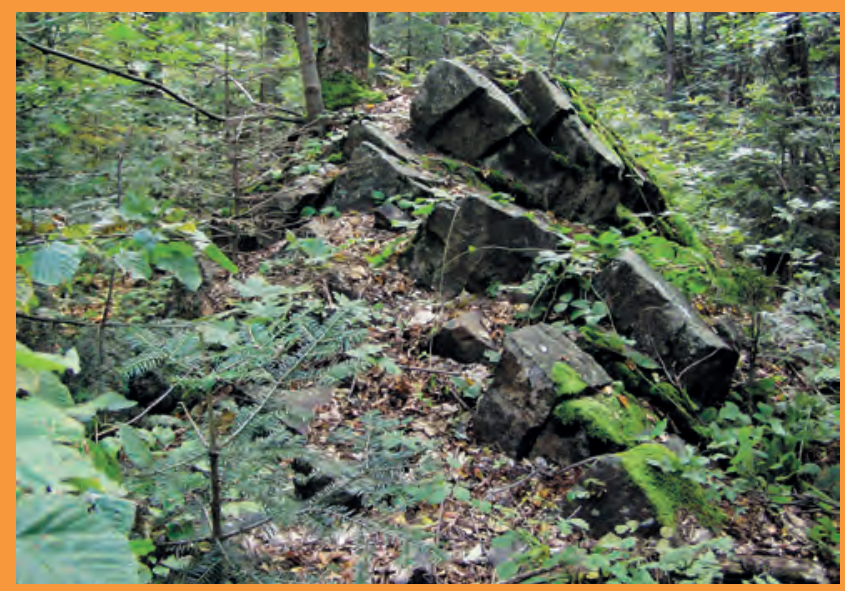

Ryc. 3C. Widna Skałka w Łysogórach od strony wschodniej

Fig. 3C. Widna Skałka crag in the Łysogóry Range, viewed from the east side

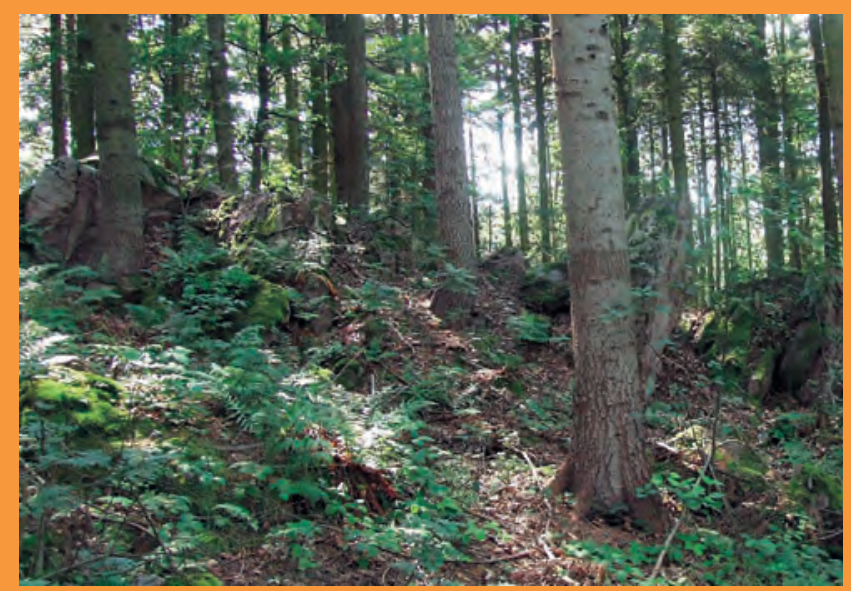

Ryc. 5C. Skałki w stanowisku Nowek-Biała Glina - środkowy fragment grzędy

Fig. 5C. Crag site Nowek-Biała Glina - middle section of the crag ridge

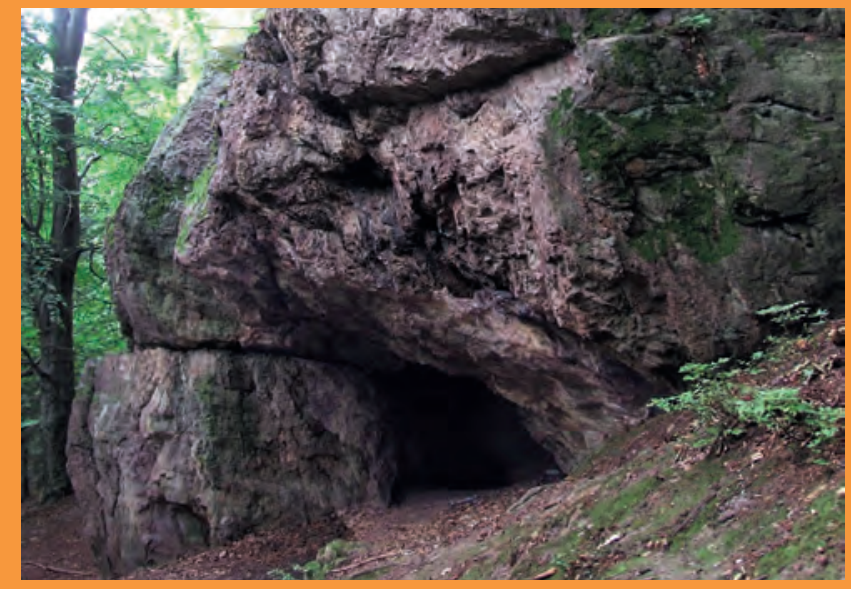

Ryc. 4F. Kamień Michniowski - skałki nr 5 i 6 z otworem Jaskini Ponurego, zaznaczone na mapce (ryc. 4A)

Fig. 4F. Kamień Michniowski - crags Nos. 5 and 6 with the entrance to Jaskinia Ponurego cave, visible on the map (Fig. 4A)

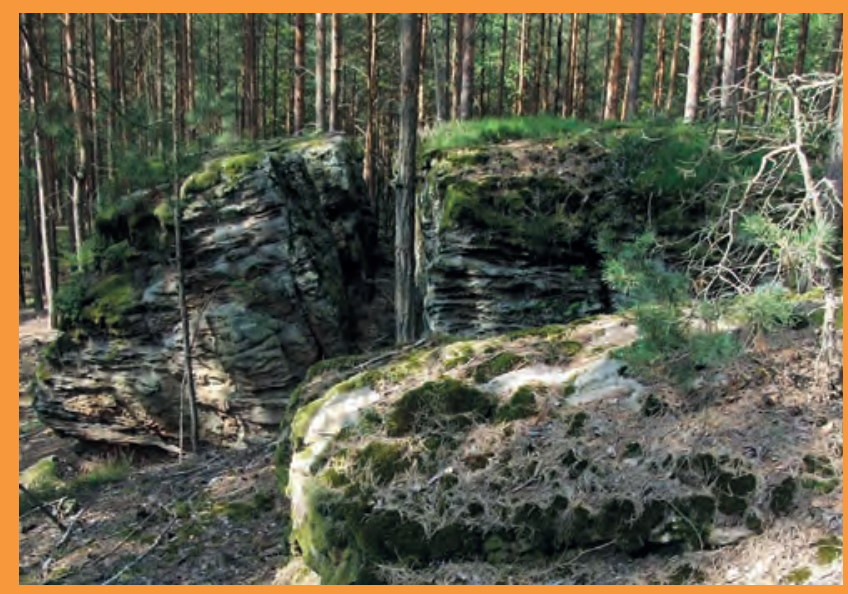

Ryc. 6H. Skałki Biały Kamień - skałki nr 3 i 4, zaznaczone na mapce (ryc. 6A)

Fig. 6H. Biały Kamień crags Nos. 3 and 4, visible on the map (Fig. 6A)

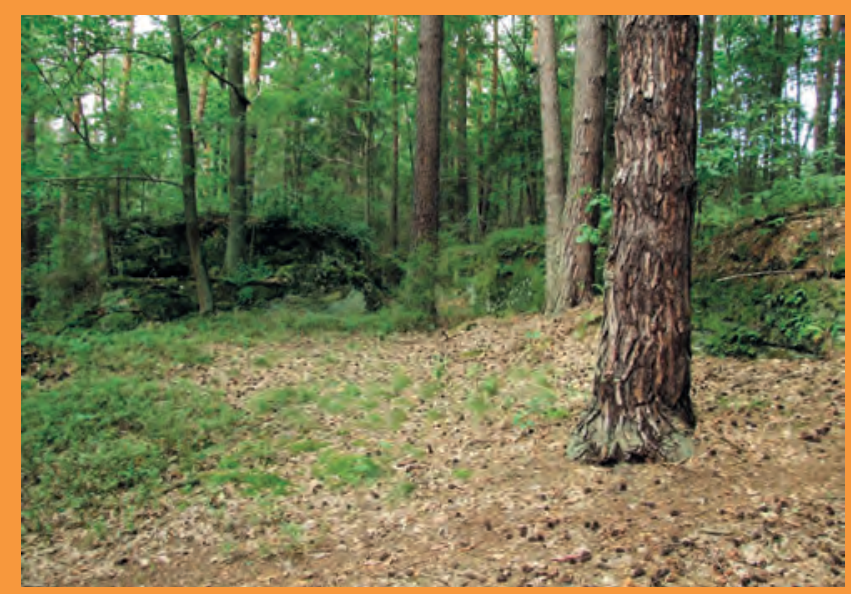

Ryc. 7G. Grupa skałkowa Adamów-Północ - skałka nr 6, widoczna na profilu (ryc. 7B). Wszystkie fot. J. Urban

Fig. 7G. Adamów-Północ crag group - crag No. 6, visible on the pro-

Fig. 6I. Biały Kamień crags - eastern part of the sub-group with crags file (Fig. 7B). All photos by J. Urban

Nos. 1 and 2 and smaller rock forms, visible on the map (Fig. 6A) 